\title{
TRP Channels as Molecular Targets to Relieve Cancer Pain
}

\author{
Milena Duitama ${ }^{1}$, Yurany Moreno ${ }^{2}$, Sandra Paola Santander ${ }^{3}$, Zulma Casas ${ }^{1}$, Jhon Jairo Sutachan ${ }^{1}$, \\ Yolima P. Torres ${ }^{1, *}$ and Sonia L. Albarracín ${ }^{1, *}$ \\ 1 Departamento de Nutrición y Bioquímica, Pontificia Universidad Javeriana, Bogotá 110231, Colombia; \\ sduitama@javeriana.edu.co (M.D.); zcasas@javeriana.edu.co (Z.C.); jsutachan@javeriana.edu.co (J.J.S.) \\ 2 Department of Lymphoma \& Myeloma, MD Anderson Cancer Center, The University of Texas, \\ Houston, TX 77030, USA; lymoreno@mdanderson.org \\ 3 Phytoimmunomodulation Research Group, Juan N. Corpas University Foundation, Bogotá 111111, Colombia; \\ paola.santander@juanncorpas.edu.co \\ * Correspondence: yolima.torres@javeriana.edu.co (Y.P.T.); albarra@javeriana.edu.co (S.L.A.)
}

check for updates

Citation: Duitama, M.; Moreno, Y.; Santander, S.P.; Casas, Z.; Sutachan,

J.J.; Torres, Y.P.; Albarracín, S.L. TRP

Channels as Molecular Targets to

Relieve Cancer Pain. Biomolecules 2022, 12, 1. https://doi.org/10.3390/ biom 12010001

Academic Editors: Maria Beatrice

Morelli and Amantini Consuelo

Received: 27 August 2021

Accepted: 23 November 2021

Published: 21 December 2021

Publisher's Note: MDPI stays neutral with regard to jurisdictional claims in published maps and institutional affiliations.

Copyright: (c) 2021 by the authors. Licensee MDPI, Basel, Switzerland. This article is an open access article distributed under the terms and conditions of the Creative Commons Attribution (CC BY) license (https:// creativecommons.org/licenses/by/ $4.0 /)$.

\begin{abstract}
Transient receptor potential (TRP) channels are critical receptors in the transduction of nociceptive stimuli. The microenvironment of diverse types of cancer releases substances, including growth factors, neurotransmitters, and inflammatory mediators, which modulate the activity of TRPs through the regulation of intracellular signaling pathways. The modulation of TRP channels is associated with the peripheral sensitization observed in patients with cancer, which results in mild noxious sensory stimuli being perceived as hyperalgesia and allodynia. Secondary metabolites derived from plant extracts can induce the activation, blocking, and desensitization of TRP channels. Thus, these compounds could act as potential therapeutic agents, as their antinociceptive properties could be beneficial in relieving cancer-derived pain. In this review, we will summarize the role of TRPV1 and TRPA1 in pain associated with cancer and discuss molecules that have been reported to modulate these channels, focusing particularly on the mechanisms of channel activation associated with molecules released in the tumor microenvironment.
\end{abstract}

Keywords: cancer; pain; TRP channels

\section{Introduction}

The tumor microenvironment (TM) can play a crucial role in the production of several signaling molecules that regulate metastasis, tumor growth, and pain. Transient receptor potential (TRP) channels are the central receptors in the transduction of nociceptive stimuli. Molecules from the TM can modulate the activity of TRP channels through the regulation of intracellular signaling pathways. Their modulation is related to the peripheral sensitization observed in patients with cancer, which results in mild noxious sensory stimuli being perceived as hyperalgesia and allodynia.

The expression of TRP channels, such as transient receptor potential vanilloid 1 (TRPV1) and transient receptor potential ankyrin 1 (TRPA1), in cells involved in detecting cancer pain and their role in pain-sensing makes them potential targets for pain relief compounds. In this review, we will describe some possible mechanisms involved in the nociception process associated with cancer that are mediated by factors produced by the TM and which could play an essential role in the direct activation or sensitization of the TRPV1 and TRPA1 channels. In addition, we will discuss the importance of several secondary metabolites derived from plant extracts that could induce the activation, blocking, or desensitization of TRP channels. These compounds could act as potential drug candidates, since their antinociceptive properties may be beneficial in relieving pain derived from cancer. 


\section{The Structure and Physiological Functions of TRP Channels}

TRP channels are tetramers formed by subunits with six transmembrane segments (S1-S6), two cytoplasmic domains $\left(\mathrm{NH}_{2}\right.$ and $\mathrm{COOH}$ termini), and a loop forming the pore between segments S5-S6 [1]. Most TRP channels are non-selective cation channels [2] that are ubiquitously expressed in mammalian tissues. Differences between TRP channel members are related to the structure of the cytosolic domains, which are characterized by the presence of specific residues in each family [3]. There are seven TRP subfamilies with different biophysical properties: TRPC (canonical), TRPV (vanilloid), TRPA (ankyrin), TRPM (melastatin), TRPP (polycystic), TRPML (mucolipin), and TRPN (no mechanoreceptor potential $C$ channels) [4].

TRPV are homo- or hetero-tetrameric calcium channels expressed on the plasma membrane. Based on their homology, the six members of the TRPV subfamily can be classified into four groups: TRPV1/TRPV2, TRPV3, TRPV4, and TRPV5/TRPV6 [4-6]. Each subunit usually includes three to five N-terminal ankyrin repeats and a TRP box at the $\mathrm{C}$ terminal (Figure 1). TRPV1, TRPV2, TRPV3, and TRPV4 are moderately $\mathrm{Ca}^{2+}$ permeable, while TRPV5 and TRPV6 are highly selective $\mathrm{Ca}^{2+}$ channels and are strictly regulated by intracellular calcium concentrations $\left(\left[\mathrm{Ca}^{2+}\right]_{\mathrm{i}}\right)[7]$.

TRPV1

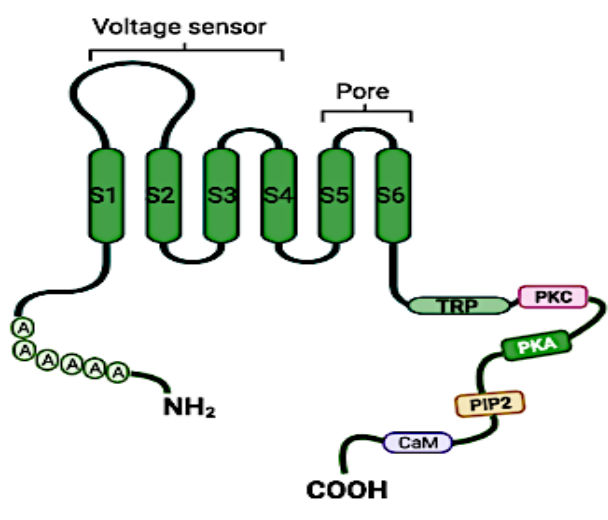

TRPA1

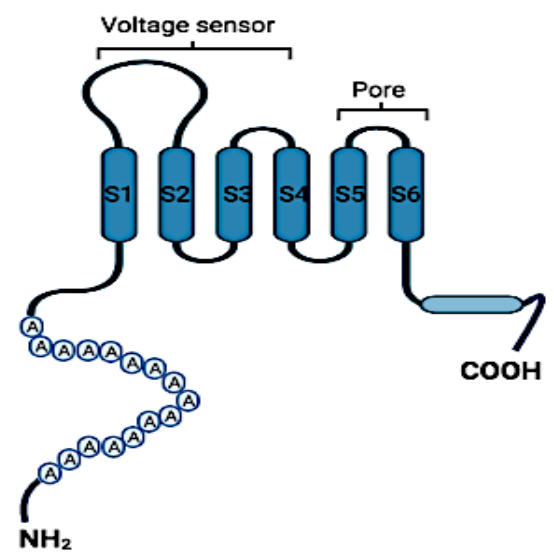

Figure 1. The structure of TRPV1 and TRPA1 channels. The general structure of these two channels includes six intracellular transmembrane domains (S1-S6), as well as carboxy (COOH), and amino $\left(\mathrm{NH}_{2}\right)$ terminals. TRPV1 and TRPA1 share 6 to 16 ankyrin repeats $(\mathrm{A})$ at the amino terminus. Binding sites for protein kinase C (PKC), protein kinase A (PKA), phosphatidylinositol 4,5 bisphosphate (PIP2), and calmodulin (CaM) have been identified on TRPV1 channels. Created with BioRender.com, accessed on 28 June 2021.

Even though TRPV family members have high sequence similarities, they have different gating properties. For instance, TRPV2-6 channels do not respond to temperature stimuli [8], and TRPV2 and TRPV4 are not sensitive to capsaicin [9]. TRPV1 channels are found in pain-sensitive neurons in the dorsal root ganglion (DRG) and trigeminal ganglion (TG) neurons [7], as well as in peripheral small unmyelinated C-fibers, and act as polymodal integrators of noxious stimuli in the skin, muscles, joints, and internal organs [8].

TRPV2 and TRPV4 channels are expressed in DRG neurons, while TRPV3 channels are found in the brain, tongue, testis [6], skin, keratinocytes, and cells surrounding hair follicles [10]. TRPV4 is expressed in non-neuronal cells, such as insulin-secreting $\beta$-cells, keratinocytes, smooth muscle cells, and different epithelial and bone cell types [11].

TRPA1, the only member of the TRPA subfamily, is a non-selective cation channel $[12,13]$. This channel has a calcium-binding domain and a voltage sensor in the C-terminal [14], 16 ankyrin repeat sequences in the $\mathrm{N}$-terminal domain $[8,15]$, and a putative selectivity filter placed at the entrance of the pore (Figure 1). Expression of the TRPA1 channel has 
been reported in the brain [16], heart [17], small intestines [18], lungs [19], bladder [20], joints [21], and skeletal muscles [22]. Furthermore, high TRPA1 expression has been observed in DRG and TG neurons [23]. In addition, TRPA1 has been reported to be a mechanosensor in peripheral sensory pathways and the inner ear [24,25].

\section{Activation Mechanisms of TRPV1 and TRPA1}

TRP channels can be activated by several ligands, second messengers, reactive oxygen and nitrogen species, and physical stimuli [26,27]. For instance, capsaicin (trans-8methyl-N-vanillyl-6-nonenamide), endocannabinoids (such as arachidonoyl ethanolamine or anandamide, and 2-arachidonylglycerol (2-AG)), cannabinoids (such as cannabidiol), lipids [28,29], and signaling molecules derived from arachidonic acid (AA) or other similar polyunsaturated fatty acids, can activate TRPs. Other stimuli, such as noxious heat $\left(>43^{\circ} \mathrm{C}\right)$, low $\mathrm{pH}(<6)[30,31]$, and membrane depolarization can also modulate TRPs [32,33].

In particular, TRPV1 can be sensitized by inflammatory molecules, such as bradykinin (BK), through G protein-coupled receptors (GPCRs) that generate second messengers such as phosphatidylinositol-4,5-biphosphate (PIP2) [34], inositol triphosphate (IP3), and diacylglycerol (DAG) [35].

Downstream effectors of these second messengers, such as protein kinase A (PKA, also commonly known as cAMP-dependent protein kinase) [36], protein kinase C (PKC) [34,37], $\mathrm{Ca}^{2+} /$ calmodulin-dependent protein kinase II (CaMKII) [38,39], and AA metabolites, like 12-HPETE [40], subsequently mediate signaling pathways critical for pain regulation. In addition, other pro-inflammatory mediators, such as prostaglandins (PGs) and sympathetic amines, can sensitize TRPV1 nociceptors, thereby, increasing pain sensation or hyperalgesia [41].

TRPA1 contributes to chemo-nociception by acting as a sensor for chemical irritants [42]. Studies have shown that some polyunsaturated fatty acids [43], as well as temperature $\left(17^{\circ} \mathrm{C}\right.$ to $\left.40^{\circ} \mathrm{C}\right)$ and $\mathrm{pH}$ changes $[13,44-46]$ promote the gating of TRPA1 channels [47]. As with TRPV1 channels, different molecules released from inflammatory environments or tissue injury sites have been shown to activate TRPA1 channels [48]. For instance, lipid peroxidation products, and activators of the inflammasome promote the stimulation of TRPA1 channels by an indirect mechanism involving $\mathrm{H}_{2} \mathrm{O}_{2}$ production [49]. Furthermore, endogenous lipidergic metabolites, like epoxyeicosatrienoic acid (EET) and PGs (such as PGA), that are produced in inflammatory environments have also been reported to activate TRPA1 channels $[45,50]$.

\section{Tumor Microenvironment (TM) and Cancer Pain}

The TM modulates cellular growth, metastasis, and angiogenesis through reciprocal communication between cancer cells and its surrounding environment. In this sense, tumor cells can promote interactions between stromal, immune, and vascular cells by releasing growth factors, chemokines, and cytokines [51]. The TM facilitates growthpromoting signals and intermediate metabolites that remodel tissue structure to build the microenvironment.

Other non-cellular components of the extracellular matrix, including collagen, fibronectin, laminin proteoglycans, and various glycoproteins [46,47], are also associated with cancer progression. Thus, the TM is highly complex and dynamic, and interactions between cells occur bidirectionally through cell-cell contacts, as well as through cell-free contacts involving vesicles that transfer information between cells or non-cellular components [52].

Interestingly, these interactions are also related to inflammatory processes. Immune cells infiltrating the tumor, together with fibroblasts and the extracellular matrix, form a scaffold, which supports expansion of the tumor by helping to establish an inflammatory environment, nourish the tumor, and promote its growth [53]. In addition, the hypoxic environment plays a critical role in early tumor development by activating genes associated with the glycolytic pathway in the tumor and inflammatory cells, such as macrophages 
and granulocytes [54]. Recruitment of these cells into the hypoxic microenvironment also contributes to the hyperproduction of reactive oxygen species (ROS) regulating the NF- $\mathrm{kB}$ pathway [55].

Under these conditions, the activation of NF- $\mathrm{kB}$ in tumor cells $[51,56]$, as well as M1 and M2 macrophages, leads to the secretion of tumor necrosis factor-alpha (TNF- $\alpha$ ) and other cytokines, such as interleukin-1 (IL-1), IL-6, IL-12, IL-10, and IL-13 [52,57]. The release of these cytokines initiates and drives the regulated expression of pro-inflammatory mediators and growth factor genes [49], such as chemokines and interferon-gamma [53,54] (Figure 2). In this review, we will discuss in further detail the pro-inflammatory mediators and growth factors that have been associated with the process of nociception.

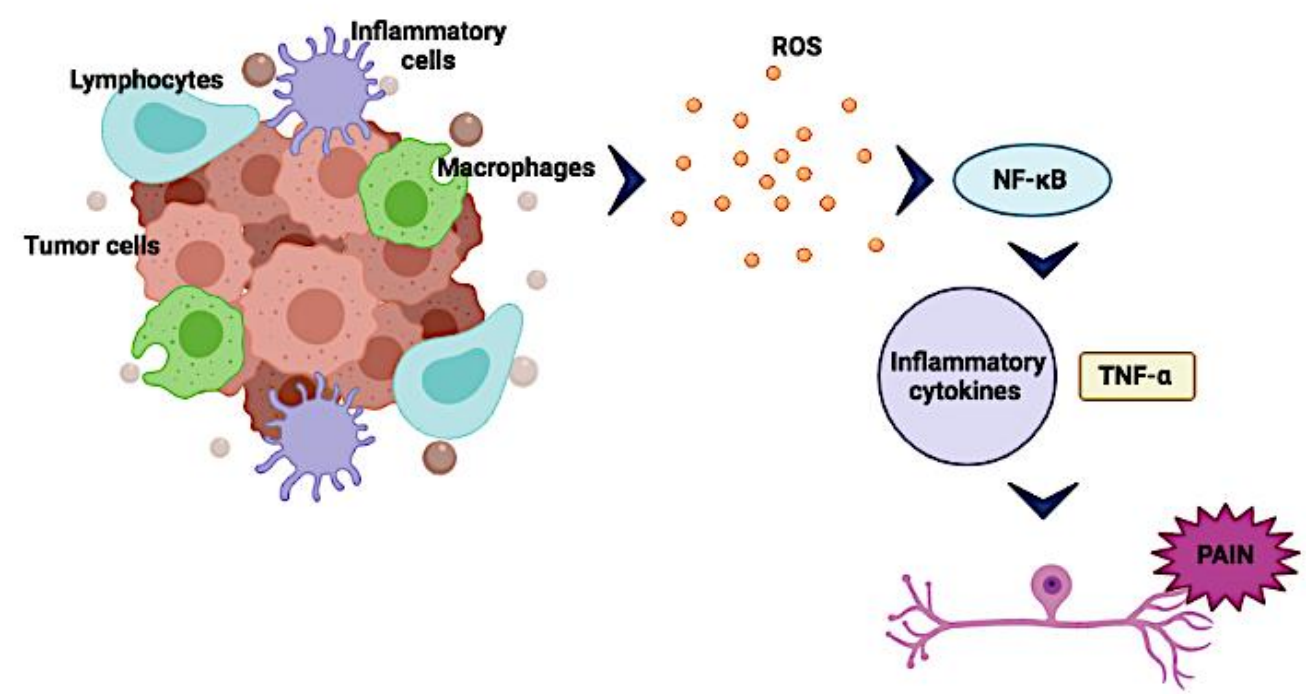

Figure 2. The tumor microenvironment and pain. Interactions between different types of cells present in the tumor are associated with inflammatory processes that induce the release of reactive oxygen species (ROS) regulating the NF- $\mathrm{kB}$ pathway within the hypoxic tumor microenvironment. Under these conditions, the activation of NF- $\mathrm{B}$, particularly in tumor cells and macrophages, induces the secretion of interleukin-6 (IL-6) and tumor necrosis factor-alpha (TNF- $\alpha$ ), which sensitize nociceptors associated with pain. Created with BioRender.com, accessed on 28 June 2021.

\subsection{Pro-Inflammatory Mediators Associated with Nociceptive Processes}

As previously mentioned, in malignant tumors, not only cancer cells but also lymphocytes, fibroblasts, and endothelial cells produce and release mediators, such as cytokines, TNF- $\alpha$, and IL-6 [58], which have been shown to be involved in modulating nociceptors [59]. Activation of these nociceptors has been associated with the onset and persistence of hyperalgesia and allodynia in cancer [60]. For example, an in vitro study using primary cultured TG neurons demonstrated that TNF $\alpha$ upregulated the trafficking of TRPV1 and TRPA1 to the surface of sensory neurons [61].

This study also demonstrated that these channels are transported in neuropeptidecontaining, large, dense-core vesicles, which allow them to modulate pain and inflammation [61]. In addition, Fang et al. used a model of bone cancer pain established by the intratibial injection of syngeneic MRMT-1 rat mammary gland carcinoma cells, and found upregulation of IL-6 and its receptors, as well as TRPV1 receptors in DRG neurons. They also reported that the IL-6/JAK/PI3K/TRPV1 signaling cascade may underlie the development of peripheral sensitization and bone cancer-induced pain [62].

Other compounds released in the TM with nociceptive effects include BK and related kinins. Some studies have shown that BK is released in response to tissue injury and plays an essential role in managing acute and chronic inflammatory pain [63]. The action of BK is mediated through the activation of B1 receptors, which are typically expressed at low but detectable levels in sensory neurons, and B2 membrane receptors, which are constitutively expressed at high levels by sensory neurons. Interestingly, B1 receptors are significantly 
upregulated after peripheral inflammation or tissue injury [64]. Notably, tumor metastasis in the skeleton has been reported to induce significant bone remodeling and tissue damage that leads to the release of BK and indirect sensitization of TRPV1 and TRPA1 channels or direct activation of TRPA1 channels [65].

Several studies have shown that nerve growth factor (NGF) is expressed and secreted by tumor and tumor-associated immune cells and reportedly regulates TRP channels $[61,66]$. NGF facilitates the innervations of the perivascular nerve to regulate blood circulation in the tumor neovessels supplying its metabolic needs [67]. In addition, NGF has a role in the nociception process as an essential mediator of chronic pain mediated through its interaction with the related receptor tyrosine kinase A (TrkA) [68], although its mechanism of action has not been fully elucidated.

A study by Jimenez-Andrade et al. used a prostate cancer pain model in the marrow space of the mouse femur to induce bone-forming cancerous foci, which allowed the tumor cells to grow and remodel the bone. This model revealed that the tumor-associated stromal cells expressed and released NGF, which drove the pathological reorganization of nearby TrkA+ sensory nerve fibers [69].

Another study with a mouse cancer model simulating the anatomical and functional features found in human oral cancer patients demonstrated that anti-NGF treatment decreased plasma TNF- $\alpha$ and IL-6 levels [70]. These results suggest that NGF can stimulate the release of pro-inflammatory mediators that bind to TrKA and modulate directly or indirectly the activity of TRPV1 and TRPA1, thereby, inducing pain in various malignancies, including breast and prostate cancers [71].

\subsection{Acidification of the Tumor Microenvironment}

Changes in $\mathrm{pH}$ have been observed in aggressive cancer cells and are considered to be an additional factor that plays an essential role in the sensitization and activation of nociceptors in the TM [72]. Cancer cells are highly dependent on glycolysis, which releases lactate and $\mathrm{H}^{+}$, particularly in deep regions where oxidative phosphorylation is reduced. Metabolic adaptation to hypoxia is driven by the master transcription factor hypoxia-inducible factor (HIF1 $\alpha$ ), which substantially increases the expression of glucose transporters and various glycolytic enzymes [73].

This metabolic reprogramming provides tumor cells with abundant energy and biosynthetic intermediates when $\mathrm{O}_{2}$ availability is limited. $\mathrm{HIF} 1 \alpha$-mediated upregulation of genes encoding lactate dehydrogenase A (LDHA) and monocarboxylate transporter 4 (MCT4) further supports increased glycolytic flux in hypoxia [74]. Specifically, pyruvate is converted by LDHA to lactate to ensure the regeneration of NAD ${ }^{+}$, while MCT4 favors the passive release of lactate out of cells along its concentration gradient. Importantly, MCT4 is a lactate $/ \mathrm{H}^{+}$symporter and plays a critical role in $\mathrm{H}^{+}$output from hypoxic cancer cells [74].

Another essential source of $\mathrm{H}^{+}$ions results from the hydration of $\mathrm{CO}_{2}$ through the action of carbonic anhydrase (CA), which generates the majority of $\mathrm{H}^{+}$and $\mathrm{HCO}_{3}{ }^{-}$produced in oxidative tumor areas. The production of $\mathrm{H}^{+}$, lactate, and $\mathrm{HCO}_{3}{ }^{-}$is essential for minimizing the accumulation of cytosolic acid. However, the extracellular accumulation of these species complicates the intracellular elimination of $\mathrm{H}^{+}$. Due to $\mathrm{CO}_{2}$ being a weaker and more diffusible acid than lactic acid, the contribution of $\mathrm{CO}_{2}$ to the reduction of intracellular $\mathrm{H}^{+}$ion concentration, arising from both glycolysis and respiration, can be considered as the most likely mechanism of acid dissipation [75].

Acidification of the TM has also been associated with nociception through the sensitization of primary sensory neurons. DRG neurons are characterized by the expression of $\mathrm{pH}$-sensitive receptors, particularly those that sense acidic $\mathrm{pH}$ and contribute to the development of pain associated with cancer. This mechanism may act synergistically with tumor-derived inflammation through the regulation of TRPV1 and TRPA1 channels [70,71]. 


\section{The Role of TRP Channels in Cancer Pain}

Several molecules including cytokines, such as TNF- $\alpha$ [64,66], IL-1 and IL-6 [76,77], TGF- $\beta$ and platelet-derived growth factor $[67,68]$, NGF, endothelin [78], PGs, BK, and epidermal growth factor [79], have been reported to directly or indirectly regulate the activity of TRPV1 and TRPA1 channels through the activation of signaling pathways downstream of GPCRs. Furthermore, other pro-inflammatory agents also act through receptor tyrosine kinases (RTKs) by activating phosphatidylinositol 3-kinase (PI3K) and ERK pathways that can induce TRP channel phosphorylation and sensitization by lowering their activation threshold, leading to the development of hyperalgesia and allodynia [80].

The activation of phospholipase C (PLC), PI3K, and adenylate cyclase (AC) have been reported to be involved in the sensitization of TRPV1 and TRPA1 after the binding of BK or NGF receptors [70-75]. In this section, we will describe some possible mechanisms that may be involved in the nociception process associated with cancer. These mechanisms are mediated by factors produced by the TM and may have an important role in the direct activation or sensitization of the TRPV1 and TRPA1 channels.

\subsection{G protein Coupled Receptor (GPCR)-Mediated Modulation of TRPV1 and TRPA1 Channel Activity}

Some inflammatory molecules are involved in the sensitization of TRPV1 and TRPA1 through the promotion of PIP2 hydrolysis into the second messengers IP3 and DAG, and subsequent increases in $\left(\left[\mathrm{Ca}^{2+}\right]_{\mathrm{i}}\right)$ [81]. In this sense, diverse GPCRs, such as proteinaseactivated receptor 2 (PAR-2) [82], purinergic receptor P2Y1 [83,84], and G-protein coupled 5-HT receptor $[85,86]$, can induce $\mathrm{Ca}^{2+}$ release by stimulating the PLC- $\beta$ pathway [87]. In this way, inflammatory mediators and neurotransmitters that activate PLC-coupled receptors can improve the sensitivity of TRP channels to other physiological stimuli [88].

For instance, it has been reported that activation of PAR-2 by intrathecal application of peptide SLIGKV-NH2 induced thermal hyperalgesia in adult Wistar rats. Interestingly, this response was blocked by pretreatment with the TRPV1 antagonist SB366791 and reduced by treatment with the protein kinase inhibitor staurosporine [89]. Together, these results suggest a functional coupling between the PAR2 and TRPV1 receptors on the central branches of DRG neurons that mediate nociception through TRPV1.

In contrast, binding of BK to its receptor activates PLC $\beta$ isoforms resulting in a moderate reduction in PIP2 levels, which releases TRPV1 channels from BK-induced inhibition (Figure 3). In addition, it has been reported that BK-mediated sensitization of TRPV1 is derived from phosphorylation of the residues S502 and S800 by PKC [90,91], suggesting that TRPV1 sensitization is mediated by both events, acting synergistically [92].

However, Lukacs and collaborators reported that maximal stimulation of TRPV1 with capsaicin led to a severe PLC $\delta$-dependent decrease in PIP2 and PIP4 in DRG neurons. The decrease in these lipids parallels an increase in channel desensitization, regulating the TRPV1 channel activity. However, these differences are likely associated with alterations in the bilayer produced by the methodologies used to incorporate PIP2 [93,94].

The role of PIP2 in the regulation of TRPV1 remains unclear. There is strong evidence showing that channel desensitization is associated with both a decrease in PIP2 [95] and an increase in $\left(\left[\mathrm{Ca}^{2+}\right]_{i}\right)[31,79]$. Using electrophysiology experiments, Lishko and collaborators showed that the binding of ATP activates TRPV1 and induces a $\mathrm{Ca}^{2+}$ influx that activates $\mathrm{Ca}^{2+}-\mathrm{CaM}$, a channel inhibitor that replaces ATP. Since both share the same binding site, they can induce the inactivation or desensitization of the channel [96]. However, another study using CaM inhibitors and CaM dominant-negative mutants demonstrated no effect on TRPV1 desensitization [97], suggesting that CaM activation is not part of the signaling pathways that regulate this channel. 


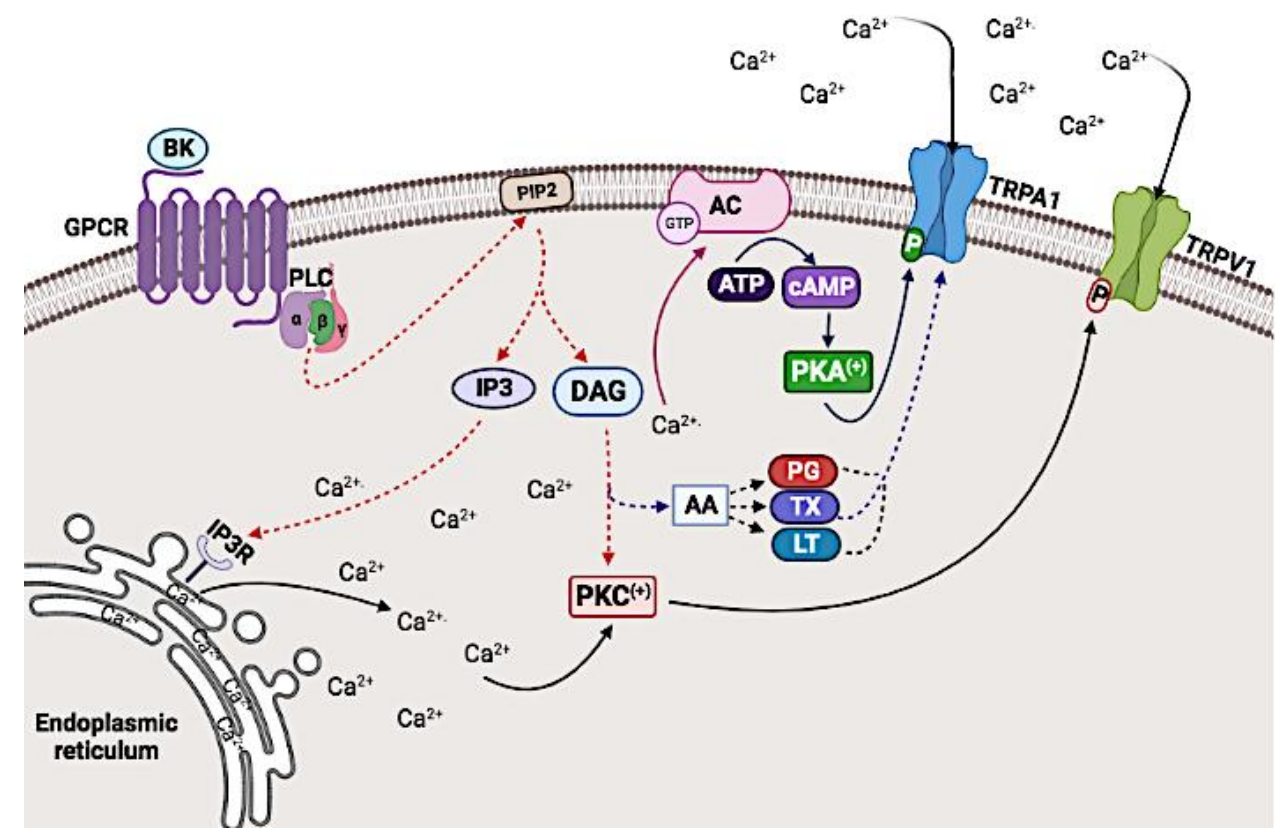

Figure 3. Modulation of the TRPV1 and TRPA1 channels by bradykinin (BK). BK binds to its BR2 receptor, which activates the phospholipase C (PLC) pathway resulting in hydrolysis of phosphatidylinositol bisphosphate (PIP2) into inositol triphosphate (IP3) and diacylglycerol (DAG). IP3 induces the release of $\mathrm{Ca}^{2+}$ from the endoplasmic reticulum, thus, increasing the intracellular $\mathrm{Ca}^{2+}$ concentration. This increase activates protein kinase C (PKC), which phosphorylates TRPV1 and activates adenylate cyclase (AC) resulting in an increase in CAMP activating protein kinase A that phosphorylates TRPA1. DAG is hydrolyzed into AA, which is the precursor for the synthesis of inflammatory mediators, such as prostaglandins (PG), thromboxanes (TX), and leukotrienes (LC), that activate TRPA1. Created with BioRender.com, accessed on 28 June 2021.

Another proposed mechanism in TRPV1 desensitization involves the protein phosphatase 2B, also called calcineurin (PP2B) $[81,91,98]$. PKC phosphorylates and sensitizes TRPV1 through the anchor protein A-kinase 150 (AKAP150) [82,99]. TRPV1 phosphorylation results in sensitization of the channel by multiple pain-inducing stimuli, including noxious heat $\left(>42{ }^{\circ} \mathrm{C}\right)$, acidic $\mathrm{pH}$, and capsaicin. Therefore, channel dephosphorylation is a critical mechanism leading to channel desensitization.

Biochemical and electrophysiological studies have shown that PP2B associates with AKAP150 and TRPV1 in cultured TG neurons and that gene silencing of AKAP150 reduces the baseline TRPV1 phosphorylation. In addition, it has been determined that capsaicin-induced TRPV1 desensitization is sensitive to inhibition of PP2B $[100,101]$ by cyclosporine $[100,102]$. However, functional studies in neurons isolated from AKAP150 ${ }^{-} /^{-}$ mice and in heterologous expression systems of TRPV1 showed that the anchor protein is not necessary for the pharmacological desensitization of the channel [103], suggesting the necessity of other molecules.

On the other hand, PGE2 released by tumor cells contributes to nociceptor sensitization by binding to the Gs-protein-coupled receptor subtypes EP3C and EP4 [104], increasing intracellular levels of cAMP and activating PKA [105]. PKA was reported to transiently sensitize capsaicin-activated currents in rat sensory neurons and potentiate heatactivated currents in HEK 293T cells that heterologously express TRPV1 [94] by Ser-116 and Thr-370 phosphorylation.

However, PKA-mediated phosphorylation of TRPV1 also involves a mechanism that decreases $\mathrm{Ca}^{2+}$-dependent channel desensitization after capsaicin activation, as was reported by Mohapatra and Nau [106]. A significant decrease in tachyphylaxis was observed when cells were pretreated for 5 min with $10 \mu \mathrm{M} \mathrm{FSK}$, an AC activator, and therefore indirect 
activator of PKA. FSK increased the current amplitude after the first application of capsaicin by approximately $47.2-50.5 \%$ between the second and fourth applications, respectively.

These findings suggest that PKA-mediated TRPV1 sensitization does not induce channel desensitization, as it does with PKC after the repeated application of capsaicin, indicating that the decreased desensitization observed after TRPV1 phosphorylation could be specific to PKA. This mechanism could contribute to the greater availability of receptors for noxious stimuli and, therefore, to the sensitization of nociceptors [106].

TRPA1 has also been shown to be modulated by bradykinin receptor 2 (BR2), a GPCR [107]. This activation can regulate the activity of TRPA1 via PLC and PKA additively or synergistically [108]. BR2-mediated regulation is thought to occur through two mechanisms. First, PLC activation induces an increase in intracellular $\mathrm{Ca}^{2+}$ concentration, which prompts activation of $\mathrm{Ca}^{2+}$-sensitive ACs, such as AC1, leading to cAMP [109] and PKA activation.

The second proposed mechanism involves the binding of BK to BR2, activating both Gq- and Gs-signaling pathways. The activation of both PLC mediated by Gq and PKA mediated by Gs/cAMP could contribute to the sensitization of TRPA1 in an additive way [108]. It has been reported that sensitization of TRPV1 by inflammatory mediators rapidly and potently improves channel activation by at least three times via PKA [110] and up to six times via PKC [111].

In contrast, for TRPA1, the PKC-dependent enhancement is substantially lower and short-term or null [108] compared to that of TRPV1 and other TRPs. Similarly, the PKA pathway has a lower effect on the activity of TRPA1 [15]. These observations suggest that PKC activation does not contribute to TRPA1 sensitization, in contrast to the sensitization mechanism proposed for TRPV1.

As mentioned above, the regulation of TRPV1 in nociceptive neurons by protein kinases is dependent on AKAP150. Zimova et al. used HEK 293T cells transfected with cDNA plasmid encoding wild-type or mutant human TRPA1 to show that AKAP150 is also necessary for the effective phosphorylation of TRPA1 by PKA and PKC. These results suggested a basal phosphorylation state or direct effect of AKAP150 on TRPA1 potentiating the channel at negative membrane potentials [112]. On the other hand, analysis of the channel sequence of TRPA1 predicted several phosphorylation sites [99,113], four of which have been considered relevant: S86, S317, and S428 in the N-terminal domain; and S972, located in the C- terminal, close to the transmembrane domain 66 [15].

The proximity of S972 to the channel pore and the TRPA1 voltage sensor [114] may explain how phosphorylation leads to channel sensitization. Phosphorylation on S972 could induce a conformational change that affects the pore by adding a polar phospho-serine to the adjacent sensor, thereby, influencing the activation of TRPA1 by voltage [15]. Thus, phosphorylation of the channel would significantly affect its activation threshold, making nociceptors more sensitive to noxious stimulation by allogeneic and pro-inflammatory agents, such as PGs, histamine, trypsin, and BK. All of these agents are present in the TM and act on GPCRs, stimulating the production of intracellular mediators that directly or indirectly activate TRPA1 [115].

Polyunsaturated fatty acids, such as AA and their metabolites, including PGs, thromboxane (TX), and leukotrienes (LT), activate TRPA1 channels [116,117]. In addition, IP3 induces activation of TRPA1 through an increase in intracellular $\mathrm{Ca}^{2+}$ released from the endoplasmic reticulum (Figure 3) [118-122]. Currently, the mechanisms that mediate cancer-induced nociception are not well-defined. However, studies have shown that inflammatory pain models provide a promising approach to study the factors involved in the development of pain in cancer. Activating these pathways sensitizes or desensitizes these channels through different controversial mechanisms and allows further understanding of this type of pain, as well as the development of possible therapeutic alternatives. 


\subsection{Modulation of the Activity of the TRPV1 and TRPA1 Channels Mediated through Receptor Tyrosine Kinase A (TrkA)}

NGF has been reported to cause hyperalgesia that can last up to days through interactions of its high-affinity receptor TrkA with TRPV1. Downstream, TrkA activates the MAP kinase (MAPK), PI3K, and PLC $\gamma$ pathways. However, it is not clear whether all three pathways are directly involved in NGF-induced pain [103-105,107-109].

The activation of PLC $\gamma$, mediated through the binding of NGF to TrkA, was initially reported to play a critical role in channel sensitization to heat responses in adult rat DRG neurons [123]. However, other studies in DRG neurons have suggested that NGF-dependent sensitization could involve the PI3K pathway, and not the ERK or PLC $\gamma$ pathways [124]. An additional study using adult rat DRG neurons demonstrated that both PI3K and ERK activation mediate inflammatory heat hyperalgesia through TRPV1 sensitization in the presence of extracellular $\mathrm{Ca}^{2+}[125]$.

Likewise, studies by Zhu and Oxford support a role for the PI3K and MAPK pathways, and not the PLC $\gamma$ pathway, in the acute sensitization of TRPV1 by NGF in response to repeated application of capsaicin. This response was detected in the presence or absence of extracellular $\mathrm{Ca}^{2+}$. An increase in $\mathrm{Ca}^{2+}$ input currents of 2.09 times and 4.23 times was observed in DRG neurons and CHO cells expressing heterologous hTrkA-TRPV1, respectively, as well as downstream PKC activation, which contributed to channel sensitization [124].

These studies also found that pre-treatment with PD98059 and LY294002, inhibitors of the ERK and PI3K pathways, respectively, completely blocked the sensitization effect to NGF, and improved the desensitization of TRPV1, which occurred after the repeated application of capsaicin [107,111,112].

Although PI3K and ERK have generally been studied as independent pathways that fulfill different physiological functions [114,115], growing evidence suggests that both pathways may be related $[114,116,117,126]$. PI3K inhibition has been reported to block capsaicin- and NGF-induced ERK activation in adult rat DRG neurons. This inhibition suggests that PI3K acts in an ERK-dependent manner, as observed in acute TRPV1 sensitization by NGF [124] and capsaicin-induced heat hyperalgesia, where PI3K was involved in the early events of hyperalgesia and ERK in its long-term maintenance [125].

Recently, Stein and colleagues reported that NGF acts through the PI3K pathway but not through the PLC pathway to facilitate the traffic of TRPV1 to the plasma membrane and its function during hyperalgesia. The authors reported that traffic regulation is mediated through the physical and functional interaction of PI3K-p $85 \beta$ with the channel. They also found that enzymatic conversion of PIP2 to PIP3 by the PI3K pathway promotes channel activation, and that although PIP2 is not an inhibitor of TRPV1 channels, it does potentiate activity in both heterologous cells and DRG neurons [91]. This last study increases the controversy surrounding the role of PIP2 in channel modulation, since the data contradict the PLC model of NGF-mediated sensitization of TRPV1, which suggests that PIP2 inhibits TRPV1, while hydrolysis of PIP2 by PLC alleviates this inhibitory effect [127].

Interestingly, this is not the first study to contradict this model of TRPV1 regulation. Previously, the perfusion of PIP2 in excised plasma membrane patches expressing TRPV1 channels has been reported to increase the effect of capsaicin, indicating that PIP2 has a positive regulatory role. The controversy regarding the role of PIP2 activity is likely associated with the methodologies used to incorporate PIP2 or liposomes versus perfusion [93,94]. Thus, although the mechanism involved in the hydrolysis of PIP2 by PLC and its role in the TRPV1 sensitization process remains unclear, the evidence thus far indicates that both the PI3K and ERK pathways are involved in NGF-mediated TRPV1 sensitization in adult rat DRG neurons.

NGF-mediated activation of TrkA may also be involved in regulating TRPA1 during p38 MAPK-dependent cold hyperalgesia in DRG neurons. In these neurons, an increase in channel expression was observed after inflammation, which coincided with the appearance of greater sensitivity to cold $\left(5^{\circ} \mathrm{C}\right)$. These findings suggested that inflammation increases 
TRPA1 expression in DRG neurons through activation of TrkA receptors and p38 kinase, and contributes to hyperalgesia associated with damaging cold [128].

Likewise, the binding of NGF to TrkA activates the PI3K pathway. One element of this signaling cascade is the tyrosine-protein kinase Src, which phosphorylates both TRPV1 and TRPA1 $[70,129,130]$. The residues Y69 [131], Y22, and Y680 in the N-terminal cytoplasmic domain of TRPA1 have been shown to be phosphorylated by Src (Figure 4). In addition, Src was reported to phosphorylate residue Y200 on TRPA1, leading to an increased channel insertion into the plasma membrane [132]. For this reason, this pathway has also been related to the upregulation of TRPA1 mediated by NGF [70,129].

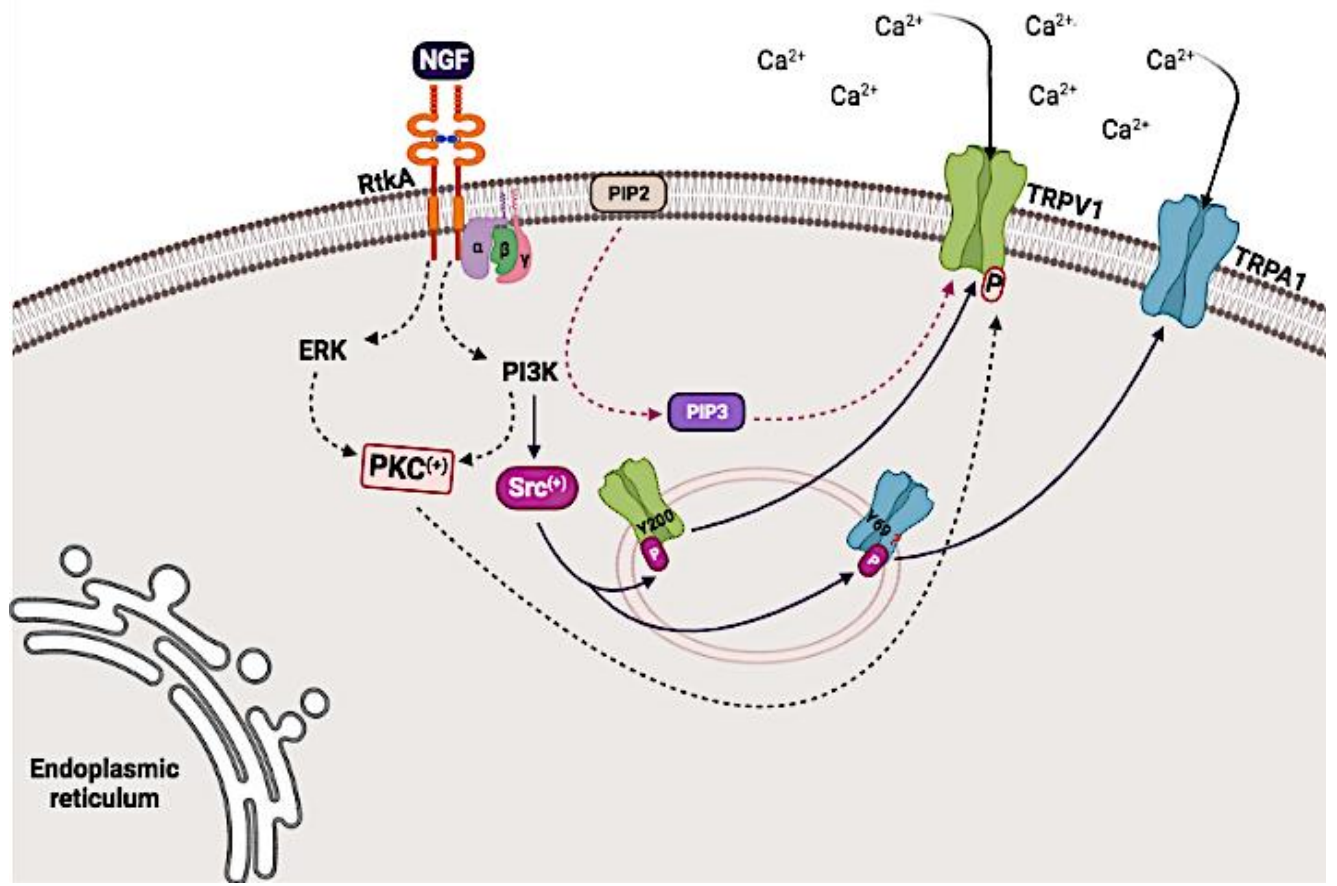

Figure 4. TRPV1 and TRPA1 channel sensitization mechanisms induced by nerve growth factor (NGF). NGF binds to its TrkA receptor to activate the MAPK-ERK and PI3K pathways, which activate protein kinase $\mathrm{C}$ (PKC) resulting in the phosphorylation and sensitization of the TRPV1 channel. Likewise, activation of PI3K mediates the enzymatic conversion of phosphatidylinositol bisphosphate (PIP2) to phosphatidylinositol triphosphate (PIP3), which promotes activation of TRPV1. Activation of PI3K leads to the activation of Src, which facilitates the trafficking of TRPA1 and TRPV1 towards the membrane. Created with BioRender.com, accessed on 28 June 2021.

A study by Diogenes and collaborators used an oral-facial pain model in adult male rats and demonstrated that a subcutaneous injection of $1 \mathrm{mg} / \mathrm{kg}$ of NGF upregulated the expression of TRPA1 in the nociceptors of the TGs sensitive to capsaicin [93]. Similar results were also reported in an oral cancer pain model, where NGF was found to upregulate the expression of both TRPA1 and TRPV1 [70]. It is believed that this positive regulation induced by NGF is closely associated with post-transcriptional modifications that regulate expression of the channels and play an essential role in the maintenance of pain associated with cancer.

In summary, these results suggest that NGF acts through the ERK and PI3K pathways to sensitize TRPV1 and TRPA1 channels, and induce hyperalgesia by heat or cold. Activation of PI3K stimulates trafficking of both channels towards the membrane, which increases their membrane expression as well as their ability to be activated or sensitized by NGF and other molecules released by the tumor. Translocation of the channel to the membrane induces the increased activity of DRG neurons that express these channels resulting in a persistent pain sensation in cancer patients. 


\subsection{Other Mechanisms}

In addition to activating signaling pathways, stimuli, such as pressure and $\mathrm{pH}$ changes, which modulate TRP channel activity, are involved in the development and persistence of pain in cancer. Tumor expansion causes pressure on surrounding organs, generating visceral pain. Several studies have reported the role of TRPA1 in mechanical sensory stimulation, particularly in harmful mechanotransduction due to nerve damage, cancer treatment, and inflammation [133]. Lennertz and collaborators reported that a subset of cutaneous primary afferent C-fibers exhibited sensitization to mechanical stimuli in inflamed tissue.

This mechanical sensitization depended on TRPA1 channel activation, since inhibition of this channel in nerve fibers that express TRPA1 significantly alleviated this hypersensitivity [134]. Based on these results, it has been suggested that primary sensory neurons contribute to inflammatory mechanical hyperalgesia through a mechanism involving TRPA1. Recently, Moparthi and Zygmunt found that human irritant receptor TRPA1 (hTRPA1) channels reconstituted in artificial lipid bilayers are sensitive to changes in bilayer pressure.

Interestingly, this effect was maintained in channels with and without $\mathrm{N}$-terminal ankyrin repeats (ARD), suggesting that ankyrin repeats are unnecessary for the TRPA1 response to mechanical stimuli $[127,135]$. However, these findings do not exclude the role of N-ARD in the coordination of mechanical stimuli and channel activity in a native environment via interactions with cell membrane lipids. Furthermore, any interaction between the channel's N-ARD cysteines and electrophilic compounds or ROS, such as $\mathrm{H}_{2} \mathrm{O}_{2}$, present in the TM $[125,136]$, could change the conformation of the protein, possibly affecting TRPA1's mechanosensitivity [133].

As previously mentioned, the low $\mathrm{pH}$ observed in aggressive cancer cells is an additional factor that plays a critical role in the sensitization and activation of nociceptors in the tumor environment. An increase in glucose consumption and lactate production decreases the $\mathrm{pH}$ at the intracellular level. Tumors regulate $\mathrm{pH}$ through MCT1 and MCT4, $\mathrm{Na}^{+} / \mathrm{H}^{+}$ exchangers, anion exchangers, carbonic anhydrases, $\mathrm{V}-\mathrm{H}^{+}$-ATPase, $\mathrm{Na}^{+} / \mathrm{HCO}_{3}{ }^{-}$cotransporters, and $\mathrm{HCO}_{3}{ }^{-}$transporters, creating an acidic extracellular cancer environment [137] with values as low as $\mathrm{pH} 6.5[123,138]$.

Of note, cancer cells that originate in several different tissues, such as the prostate, breast, and lung, have a propensity to metastasize to the bone microenvironment [139]. The tumor burden within the bone causes unbearable breakthrough pain with properties of continuous pain [140]. Bone colonized by solid cancer generates an acidic extracellular microenvironment mediated by osteoclasts releasing protons and hydrochloric acid to degrade bone minerals during bone resorption [141].

The acidosis is allogenic for sensory neurons. TRPV1 and TRPA1 could be involved in the development of cancer-associated pain, mediated by the acidic tumor environment. For example, extracellular acidification has been reported to activate TRPV1 with a $\mathrm{pH}$ below 6.4 and sensitize the channels at pHs greater than 7.4 [31]. This induces a shift in its activation threshold towards lower temperature or ligand concentration, through the protonation of the extracellular Glu residue (E600) located between the fifth transmembrane domain and the putative pore-forming region [142].

In addition to the modulation by extracellular proton concentration, TRPV1 activity is also regulated by intracellular acidification in both heterologous expression systems and nociceptive DRG neurons. In conditions where the external $\mathrm{pH}$ is neutral, the intracellular acidification induced after channel activation by capsaicin was strictly coupled to a $\mathrm{Ca}^{2+}$ input component [143], which could be mediated through any of the following three proposed mechanisms. First, a mitochondrial $\mathrm{Ca}^{2+}$ clearance pathway that leads to negative potential collapse across the inner mitochondrial membrane and subsequent TRPV1 proton leakage [144]; second, the proton displacement of $\mathrm{Ca}^{2+}$ buffer proteins [91,128]; and third, an antiport of $\mathrm{Ca}^{2+}-\mathrm{H}^{+}$by $\mathrm{Ca}^{2+}$-ATPases, in the semipermeable membrane that encloses the cytoplasm [145]. 
Although it remains unclear as to which of these mechanisms mediates intracellular acidification after the activation of TRPV1, the evidence shows that this effect could also activate TRPA1 channels. Wang and collaborators found that intracellular acidification by weak acids, such as carbonic, acetic, and propionic acid released protons into the intracellular medium, thereby, activating TRPA1 in sensory TG neurons [146]. These results suggest that, in a tumor environment, acidification of the extracellular medium could induce a synergistic effect between TRPV1 and TRPA1.

After activation of TRPV1, the decrease in intracellular $\mathrm{pH}$ would be sensed by TRPA1, and induce their activation. These effects result in the potentiation of the nociceptive sensory neurons that co-express both channels. Recently, de la Roche and collaborators reported that extracellular acidosis activated and sensitized the hTRPA1 through a mechanism that did not involve modification of $\mathrm{N}$-cysteine intracellular terminals as essential sites of interaction for TRPA1 electrophilic agonists [45]. This finding further implicates TRPA1 in proton-induced pain transduction, particularly in cancer-associated pain.

\section{The Role of TRP Channel Agonists and Antagonists in Cancer Pain}

TRPV1 and TRPA1 are found in nociceptors that transduce information associated with noxious stimuli and participate in pain response. Therefore, regulating TRPV1 and TRPA1 channel activity with antagonists or stimulating them with agonists until they become desensitized could result in a strategic tool that would promote an analgesic effect [147].

TRPA1 antagonists have been used in different pain models and have shown a higher analgesic activity and common side effects. Studies in diabetic mice, for example, have shown that some TRPA1 antagonists improve mechanical hyperalgesia and prevent the loss of skin nerve fibers $[43,139]$. Such findings have led to the identification and evaluation of new molecules in preclinical and clinical studies. Two synthetic antagonists, CB-625 and GRC15736, have been tested in models of acute post-surgical pain and diabetic peripheral neuropathy with promising results [147].

Since TRPA1 channels have been shown to be important in the transduction of pain in cancer, evaluations of these antagonists in pain cancer models would be valuable. However, the use of some synthetic antagonists, particularly in TRPV1 channels, has been reported to increase the heat pain threshold after their administration, generating scalding lesions $[134,148,149]$. In other cases, the development of hyperthermia, which lasted up to 4 days, with body temperatures close to $40.2^{\circ} \mathrm{C}$ was reported [147]. Hyperthermia has been shown to occur through TRPV1 activation due to an increase in the concentration of hydronium ions [150].

Therefore, antagonists that interfere with acid $\mathrm{pH}$-mediated activation of TRPV1 could be used to inhibit the effect of hydronium ions. However, this concept is still controversial, as it is true for some compounds, such as AS1928370 and A-1165442 [137,150], but not for others including PHE377 and JTS-653 [150-152]. Thus, further studies are required to elucidate the mechanism of action of these compounds on channel activity, particularly in a tumor environment, which, as previously described, is characterized by a decrease in extracellular $\mathrm{pH}$.

In contrast to the challenges associated with the development of antagonists, agonists have been used clinically to locally desensitize TRP channels with only mild side effects, such as irritation. This notion of a paradoxical use of TRP channel agonists as pain regulators has been derived from the experience of specific herbal remedies used in traditional medicine. For example, preparations or recipes containing TRP channel agonists, such as cinnamaldehyde (TRPA1) or shogaol (TRPV1), have long been used topically or orally to relieve neuralgia, arthralgia, menstrual pain, and headaches [147].

As mentioned above, capsaicin, the main pungent component in the fruit of the plants of the genus Capsicum, is the primary agonist of TRPV1 [153]. Capsaicin is a naturally occurring alkaloid member of vanilloid compounds, such as vanilla, vanillin, eugenol, 
and zingerone [154]. Capsaicin initially activates TRPV1, but after repeated stimulation, it causes a long-lasting refractory period, termed desensitization [155].

This process has been studied for its therapeutic potential in managing pain, such as osteoarthritis and postsurgical pain $[153,156]$. An analgesic effect has been reported possibly attributed to the degeneration of epidermal nerve fibers [157], which could be mediated by apoptosis through the activation of caspases. However, the mechanisms by which the application of capsaicin induces this degeneration in sensory fibers have not been established [158].

Currently, topical formulations of capsaicin are widely used for the treatment of pain. It has been reported that low doses of capsaicin between $0.025 \%$ and $0.075 \%$ are not particularly effective in treating different forms of chronic neuropathic pain and musculoskeletal pain. However, it does seem to have a clinical benefit for pain treatment [159] in postherpetic neuralgia [159,160], and painful diabetic neuropathy [161]. Furthermore, the use of topical capsaicin at $0.075 \%$ applied four times a day for three weeks caused degeneration of skin nerve fibers and, consequently, decreased sensitivity to cold and tactile stimuli, but not to heat and mechanical stimuli [157].

In contrast, the use of topical capsaicin at doses between $5 \%$ and $10 \%$, together with the application of local anesthesia, were shown to provide significant relief from neuropathic pain, post-traumatic neuropathy, postsurgical neuralgia, and mixed pain syndrome [161-163]. In addition, 8\% capsaicin topical patches are available under Qutenza or Transacin for use in patients with postherpetic neuralgia and peripheral neuropathy [164]. However, diverse adverse effects have been reported, including pain, pruritus, skin erythema, papules, and a transient increase in blood pressure [165].

Capsaicin has been used by patients with cancer pain derived from surgeries, chemotherapy, and radiotherapy. The topical use of capsaicin $0.075 \%$, four times a day, has been reported in patients with neuropathic pain resulting from surgery, with good acceptability of the treatment despite side effects [166]. Likewise, temporary pain relief has been reported after using oral capsaicin in patients with mucositis due to chemotherapy or radiotherapy [167].

Finally, the use of $8 \%$ capsaicin patches was reported in patients with post-traumatic neuropathic pain with an $80 \%$ reduction in allodynia up to 18 months after its application [162]. Although capsaicin induces some adverse side effects, it is well-tolerated, and thus pharmacological strategies, such as the use of anesthetics that attenuate or improve discomfort, coupled to the application of capsaicin have been implemented.

Resiniferatoxin (RTX) is another TRPV1 agonist that has shown promising effects for pain management, particularly in bone cancer. This ultra-potent capsaicin analog, present in the latex of a cactus-like plant, Euphorbia resinifera, mimics most of the biological characteristics of capsaicin, with a potency of approximately 1000 times, which induces channel desensitization [168].

In animal models, RTX treatment was found to induce the desensitization of TRPV1expressing neurons and improved bone cancer pain, providing relief for several weeks in mice and dogs with advanced osteosarcoma [153-156]. This effect was mimicked by the pharmacological blockade of the TRPV1 gene and channel by the selective antagonist JNJ17203212 [169]. In addition, epidural application of RTX is well tolerated at doses that induce analgesia ( $0.265 \mathrm{mg}$ in rats), although some adverse effects have been reported (sedation or hyperventilation) at doses approximately 10-times higher, as well as death at doses greater than $10 \mathrm{mg}$ [170].

Clinical studies are currently underway that involve the administration of 3 to $26 \mu \mathrm{g}$ of intrathecal RTX [171] in patients over 18 years of age with advanced stages of cancer and chronic and intractable pain (clinicaltrials.gov, NCT00804154). Patients who received the lowest doses of RTX experienced varying levels of pain relief, while patients who received RTX injections of 13 or $26 \mu \mathrm{g}$ reported less pain and better mobility [171].

Furthermore, the reduction in thermal perception was consistent with the death of TRPV1-expressing neurons, without any other sensory or motor changes after treatment. 
These findings suggest that intrathecal RTX administration can selectively induce cell death in pain-transmitting neurons [172], which is consistent with the reported ability of RTX to alleviate pain $[160,173]$. These results have not only provided the basis for the development of new specific analgesics for managing this type of pain, but have also contributed to the expansion of novel approaches to identify compounds of plant origin, particularly species that have traditionally been used for pain management.

Many secondary metabolites are present in plant extracts and can directly modulate the activity of the TRPV1 and TRPA1 channels (Table 1). Some traditional plants used for the treatment of pain also have one or more of these metabolites. Compounds, such as tannins, anacardial acid present in extracts of Anacardium occidentale L [174], eugenol and linalol identified in extracts of Bidens Pilosa [175,176], camphor and linalool from Piper aduncum extracts [177,178], and carvone and geraniol from Lippia alba [179], may be involved in the potential analgesic effects of these extracts [174,180,181]. However, further studies are required to elucidate the mechanisms mediating the observed effects [181].

Table 1. Plant-derived compounds that could potentially modulate the activity of the transient receptor potential channels, TRPV1 and TRPA1.

\begin{tabular}{|c|c|c|c|c|c|}
\hline \multirow{2}{*}{ Channel } & \multirow{2}{*}{ Compound } & \multirow{2}{*}{ Source } & \multicolumn{2}{|c|}{ Activity } & \multirow{2}{*}{ Reference } \\
\hline & & & Agonist & Antagonist & \\
\hline \multirow{9}{*}{ TRPV1 } & Capsaicin & Capsicum & $t$ & & [30] \\
\hline & Piperine & Piper nigrum & $\dagger$ & & [182] \\
\hline & Resiniferatoxin & Euphorbia resinifera & + & & [30] \\
\hline & Evodiamine & Evodia rutaecarpa & + & & [183] \\
\hline & Cannabidiol & Cannabis sativa & + & & [184] \\
\hline & Polygodial & Polygonum hydropiper & + & & [185] \\
\hline & Isovelleral & Lactarius vellereus & + & & [186] \\
\hline & Tapsigargina & Thapsia garganica & & $\dagger$ & [187] \\
\hline & Yohimbine & Pausinystalia yohimbe & & + & [188] \\
\hline \multirow{10}{*}{ TRPA1 } & $\begin{array}{c}\text { Allyl } \\
\text { isothiocyanate }\end{array}$ & Wasabi, mustard oil & + & & [189] \\
\hline & $\begin{array}{c}\text { Benzyl } \\
\text { isothiocyanate }\end{array}$ & Yellow mustard & $\dagger$ & & [189] \\
\hline & $\begin{array}{c}\text { Phenylethyl } \\
\text { isothiocyanate }\end{array}$ & Brussels sprouts & + & & [189] \\
\hline & $\begin{array}{c}\text { Isopropyl } \\
\text { isothiocyanate }\end{array}$ & Nasturtium seeds & + & & [189] \\
\hline & $\begin{array}{c}\text { Methyl } \\
\text { isothiocyanate }\end{array}$ & Capparis spinosa & + & & [189] \\
\hline & Cinnamaldehyde & $\begin{array}{c}\text { Cinnamomum } \\
\text { cassia/Cinnamomum } \\
\text { zeylanicum }\end{array}$ & + & & [126] \\
\hline & Methyl salicylate & Wintergreen oil & + & & [126] \\
\hline & Carvacrol & Origanum genus & + & & [190] \\
\hline & Tetrahydrocannabinol & Cannabis genus & $\dagger$ & & [189] \\
\hline & Menthol & Mentha & & + & [191] \\
\hline \multirow{4}{*}{ Both of them } & Eugenol & Clove oil & TRPV1/TRPA1 & & [192] \\
\hline & Gingerol & Zingiber officinale & TRPV1/TRPA1 & & {$[126,193]$} \\
\hline & Camphor & Cinnamomum camphora & TRPV1 & TRPA1 & [194] \\
\hline & Allicin & Allium sativum & TRPV1/TRPA1 & & [195] \\
\hline
\end{tabular}

+ Compounds that modulate TRPV1 and TRPA1 as agonists or antagonists.

These findings allow the identification of new compounds, which may have the potential to regulate these channels and could, therefore, become pharmacological candidates, for example, to treat cancer pain, either as new analgesics or as adjuvants to cancer treatment. A promising alternative in this field would be the use of plant extracts traditionally 
used to manage different types of pain, which consist of compounds with antinociceptive effects [196].

\section{Conclusions}

The mechanisms associated with cancer pain have not yet been fully elucidated, due to the various molecules and complex processes, which may be involved in its generation and progression. However, we propose that mechanisms that participate in the nociception process in pain are modulated by TRPV1 and TRPA1 channels. Evidence suggests that inflammatory mediators, as well as the enhanced acidification of the extracellular and intracellular components of the TM, regulate the activity of these channels through signaling pathways.

The PLC, PI3K, and MAPK-ERK signaling pathways, activate downstream kinases, such as PKC and PKA, which phosphorylate TRPV1 and TRPA1 channels and promote channel sensitization and reduction of their activation threshold, potentially contributing to the pain sensation experienced by cancer patients. Further evidence suggests that secondary metabolites from traditional plants used for pain management can regulate the activity of these channels. Thus, it would be interesting in the future to examine new molecules with potential antinociceptive properties that are associated with TRPV1 and TRPA1 modulation. The identification of such molecules could lead to the development of treatment strategies with enhanced pain-relieving effects and fewer side effects than the analgesics currently available.

Author Contributions: Conceptualization, M.D., Y.P.T. and S.L.A.; writing-review and editing, M.D., Y.M., S.P.S., Z.C., J.J.S., Y.P.T. and S.L.A. All authors have read and agreed to the published version of the manuscript.

Funding: Ministerio de Educación Nacional, Ministerio de Industria, Comercio y Turismo, ICETEX and World Bank (792-2017 2a Convocatoria Ecosistema Científico-Colombia Científica para la financiación de proyectos de I+D+i). Vicerrectoría de Investigación, Pontificia Universidad Javeriana, Grant ID 20278. Plant extracts with antinociceptive potential that modulate the Transient receptor potential ankyrin 1 (TRPA1).

Institutional Review Board Statement: Not applicable.

Informed Consent Statement: Not applicable.

Conflicts of Interest: The authors declare no conflict of interest.

\section{References}

1. Catterall, W.A.; Swanson, T.M. Structural basis for pharmacology of voltage-gated sodium and calcium channels. Mol. Pharmacol. 2015, 88, 141-150. [CrossRef] [PubMed]

2. Harteneck, C.; Plant, T.D.; Schultz, G. From worm to man: Three subfamilies of TRP channels. Trends Neurosci. 2000, 23, 159-166. [CrossRef]

3. Gaudet, R. TRP channels entering the structural era. J. Physiol. 2008, 586, 3565-3575. [CrossRef] [PubMed]

4. Nilius, B.; Owsianik, G. The transient receptor potential family of ion channels. Genome Biol. 2011, 12, 218. [CrossRef]

5. Smith, G.D.; Gunthorpe, M.J.; Kelsell, R.E.; Hayes, P.D.; Reilly, P.; Facer, P.; Wright, J.E.; Jerman, J.C.; Walhin, J.-P.; Ooi, L.; et al. TRPV3 is a temperature-sensitive vanilloid receptor-like protein. Nature 2002, 418, 186-190. [CrossRef] [PubMed]

6. Xu, H.; Ramsey, I.S.; Kotecha, S.A.; Moran, M.M.; Chong, J.A.; Lawson, D.; Ge, P.; Lilly, J.; Silos-Santiago, I.; Xie, Y.; et al. TRPV3 is a calcium-permeable temperature-sensitive cation channel. Nature 2002, 418, 181-186. [CrossRef]

7. Gees, M.; Colsoul, B.; Nilius, B. The role of transient receptor potential cation channels in Ca ${ }^{2+}$ signaling. Cold Spring Harb. Perspect. Biol. 2010, 2, a003962. [CrossRef]

8. Samanta, A.; Hughes, T.E.T.; Moiseenkova-Bell, V.Y. Transient receptor potential (TRP) channels. In Subcellular Biochemistry; Springer: New York, NY, USA, 2018; pp. 141-165.

9. Caterina, M.J.; Rosen, T.A.; Tominaga, M.; Brake, A.J.; Julius, D. A capsaicin-receptor homologue with a high threshold for noxious heat. Nature 1999, 398, 436-441. [CrossRef]

10. Mandadi, S.; Sokabe, T.; Shibasaki, K.; Katanosaka, K.; Mizuno, A.; Moqrich, A.; Patapoutian, A.; Fukumi-Tominaga, T.; Mizumura, K.; Tominaga, M. TRPV3 in keratinocytes transmits temperature information to sensory neurons via ATP. Pflügers Archiv. 2009, 458, 1093-1102. [CrossRef] 
11. Vennekens, R.; Owsianik, G. Vanilloid transient receptor potential cation channels: An overview. Curr. Pharm. Des. 2008, $14,18-31$.

12. Legrand, C.; Merlini, J.M.; De Senarclens-Bezençon, C.; Michlig, S. New natural agonists of the transient receptor potential Ankyrin 1 (TRPA1) channel. Sci. Rep. 2020, 10, 11238. [CrossRef]

13. Laursen, W.J.; Bagriantsev, S.N.; Gracheva, E.O. TRPA1 channels: Chemical and temperature sensitivity. In Current Topics in Membranes; Elsevier: Amsterdam, The Netherlands, 2014; Volume 74, pp. 89-112. [CrossRef]

14. Meents, J.E.; Ciotu, C.I.; Fischer, M.J.M. Trpa1: A molecular view. J. Neurophysiol. 2019, 121, 427-443. [CrossRef]

15. Meents, J.E.; Fischer, M.J.; McNaughton, P.A. Sensitization of TRPA1 by protein kinase A. PLoS ONE 2017, 12, e0170097. [CrossRef] [PubMed]

16. Kheradpezhouh, E.; Choy, J.M.C.; Daria, V.R.; Arabzadeh, E. TRPA1 expression and its functional activation in rodent cortex. Open Biol. 2017, 7, 160314. [CrossRef] [PubMed]

17. Andrei, S.R.; Sinharoy, P.; Bratz, I.N.; Damron, D.S. TRPA1 is functionally co-expressed with TRPV1 in cardiac muscle: Colocalization at z-discs, costameres and intercalated discs. Channels 2016, 10, 395-409. [CrossRef] [PubMed]

18. Yang, Y.; Wang, S.; Kobayashi, K.; Hao, Y.; Kanda, H.; Kondo, T.; Kogure, Y.; Yamanaka, H.; Yamamoto, S.; Li, J.; et al. TRPA1-expressing lamina propria mesenchymal cells regulate colonic motility. JCI Insight 2019, 9, e122402. [CrossRef]

19. Büch, T.R.H.; Schäfer, E.A.M.; Demmel, M.-T.; Boekhoff, I.; Thiermann, H.; Gudermann, T.; Steinritz, D.; Schmidt, A. Functional expression of the transient receptor potential channel TRPA1, a sensor for toxic lung inhalants, in pulmonary epithelial cells. Chem. Biol. Interact. 2013, 206, 462-471. [CrossRef]

20. Du, S.; Araki, I.; Kobayashi, H.; Zakoji, H.; Sawada, N.; Takeda, M. Differential expression profile of cold (TRPA1) and cool (TRPM8) receptors in human urogenital organs. Urology 2008, 72, 450-455. [CrossRef]

21. Kochukov, M.; McNearney, T.A.; Fu, Y.; Westlund, K.N. Thermosensitive TRP ion channels mediate cytosolic calcium response in human synoviocytes. Am. J. Physiol. Cell Physiol. 2006, 291, C424-C432. [CrossRef]

22. Osterloh, M.; Böhm, M.; Kalbe, B.; Osterloh, S.; Hatt, H. Identification and functional characterization of TRPA1 in human myoblasts. Pflügers Archiv. 2015, 468, 321-333. [CrossRef]

23. Takahashi, N.; Mizuno, Y.; Kozai, D.; Yamamoto, S.; Kiyonaka, S.; Shibata, T.; Uchida, K.; Mori, Y. Molecular characterization of TRPA1 channel activation by cysteine-reactive inflammatory mediators. Channels 2008, 2, 287-298. [CrossRef]

24. Corey, D.P.; Garcia-Añoveros, J.; Holt, J.R.; Kwan, K.Y.; Lin, S.Y.; Vollrath, M.A.; Zhang, D.S. TRPA1 is a candidate for the mechanosensitive transduction channel of vertebrate hair cells. Nature 2004, 432, 723-730. [CrossRef] [PubMed]

25. Nagata, K.; Duggan, A.; Kumar, G.; García-Añoveros, J. Nociceptor and hair cell transducer properties of TRPA1, a channel for pain and hearing. J. Neurosci. 2005, 25, 4052-4061. [CrossRef] [PubMed]

26. Nilius, B. Transient Receptor Potential (TRP) channels in the Brain: The good and the ugly. Eur. Rev. 2012, 20, 343-355. [CrossRef]

27. Katz, B.; Payne, R.; Minke, B. TRP channels in vision. In Neurobiology of TRP Channels; CRC Press: Boca Raton, FL, USA, 2017; pp. 27-63.

28. Cortright, D.W.; Szallasi, A. Biochemical pharmacology of the vanilloid receptor TRPV1: An update. Eur. J. Biochem. 2004, 271, 1814-1819. [CrossRef]

29. Jung, J.; Shin, J.S.; Lee, S.Y.; Hwang, S.W.; Koo, J.; Cho, H.; Oh, U. Phosphorylation of vanilloid receptor 1 by Ca ${ }^{2+} / \mathrm{Calmodulin}^{-}$ dependent kinase II regulates Its vanilloid binding. J. Biol. Chem. 2004, 279, 7048-7054. [CrossRef] [PubMed]

30. Caterina, M.J.; Schumacher, M.A.; Tominaga, M.; Rosen, T.A.; Levine, J.D.; Julius, D. The capsaicin receptor: A heat-activated ion channel in the pain pathway. Nature 1997, 389, 816-824. [CrossRef]

31. Tominaga, M.; Caterina, M.J.; Malmberg, A.B.; Rosen, T.A.; Gilbert, H.; Skinner, K.; Julius, D. The cloned capsaicin receptor integrates multiple pain-producing stimuli. Neuron 1998, 21, 531-543. [CrossRef]

32. Cao, E. Structural mechanisms of transient receptor potential ion channels. J. Gen. Physiol. 2020, 152, e201811998. [CrossRef]

33. Hwang, I.; Harper, J.F.; Liang, F.; Sze, H. Calmodulin activation of an endoplasmic reticulum-located calcium pump involves an interaction with the N-terminal autoinhibitory domain. Plant Physiol. 2000, 122, 157-168. [CrossRef]

34. Bhave, G.; Zhu, W.; Wang, H.; Brasier, D.J.; Oxford, G.S.; Gereau, R.W., IV. cAMP-dependent protein kinase regulates desensitization of the capsaicin receptor (VR1) by direct phosphorylation. Neuron 2002, 35, 721-731. [CrossRef]

35. Burgess, G.; Mullaney, I.; McNeill, M.; Dunn, P.; Rang, H. Second messengers involved in the mechanism of action of bradykinin in sensory neurons in culture. J. Neurosci. 1989, 9, 3314-3325. [CrossRef] [PubMed]

36. Vlachová, V.; Teisinger, J.; Sušánková, K.; Lyfenko, A.; Ettrich, R.; Vyklický, L. Functional role of C-terminal cytoplasmic tail of rat vanilloid receptor 1. J. Neurosci. 2003, 23, 1340-1350. [CrossRef] [PubMed]

37. Varga, V.; Helenius, J.; Tanaka, K.; Hyman, A.; Tanaka, T.; Howard, J. Yeast kinesin-8 depolymerizes microtubules in a lengthdependent manner. Nature 2006, 8, 957-962. [CrossRef] [PubMed]

38. Rosenbaum, T.; Gordon-Shaag, A.; Munari, M.; Gordon, S.E. Ca ${ }^{2+} /$ Calmodulin modulates TRPV1 activation by capsaicin. J. Gen. Physiol. 2004, 123, 53-62. [CrossRef]

39. Jin, X.; Morsy, N.; Winston, J.; Pasricha, P.J.; Garrett, K.; Akbarali, H.I. Modulation of TRPV1 by nonreceptor tyrosine kinase, c-Src kinase. Am. J. Physiol. Cell Physiol. 2004, 287, 558-563. [CrossRef]

40. Shin, J.; Cho, H.; Hwang, S.W.; Jung, J.; Shin, C.Y.; Lee, S.-Y.; Kim, S.H.; Lee, M.G.; Choi, Y.H.; Kim, J.; et al. Bradykinin12-lipoxygenase-VR1 signaling pathway for inflammatory hyperalgesia. Proc. Natl. Acad. Sci. USA 2002, 99, 10150-10155. [CrossRef] 
41. Zarpelon, A.C.; Cunha, T.M.; Alves-Filho, J.C.; Pinto, L.G.; Ferreira, S.H.; McInnes, I.B.; Verri, W.A., Jr. IL-33/ST2 signalling contributes to carrageenin-induced innate inflammation and inflammatory pain: Role of cytokines, endothelin-1 and prostaglandin $\mathrm{E}$ 2. Br. J. Pharmacol. 2013, 169, 90-101. [CrossRef] [PubMed]

42. Yu, L.-J.; Wang, X.-L.; Cui, L.-W.; Liu, Z.; Gao, Y.-M.; Wang, S.; Li, H.; Liu, H.-X. Effects of TRPA1 activation and inhibition on TRPA1 and CGRP expression in dorsal root ganglion neurons. Neural Regen. Res. 2019, 14, 140. [CrossRef]

43. Viana, F. TRPA1 channels: Molecular sentinels of cellular stress and tissue damage. J. Physiol. 2016, 594, 4151-4169. [CrossRef]

44. Moparthi, L.; Kichko, T.I.; Eberhardt, M.; Högestätt, E.D.; Kjellbom, P.; Johanson, U.; Zygmunt, P.M. Human TRPA1 is a heat sensor displaying intrinsic U-shaped thermosensitivity. Sci. Rep. 2016, 6, 28763. [CrossRef] [PubMed]

45. De La Roche, J.; Eberhardt, M.J.; Klinger, A.B.; Stanslowsky, N.; Wegner, F.; Koppert, W.; Leffler, A. The molecular basis for species-specific activation of human TRPA1 protein by protons involves poorly conserved residues within transmembrane domains 5 and 6. J. Biol. Chem. 2013, 288, 20280-20292. [CrossRef]

46. Zimova, M.; Hackländer, K.; Good, J.M.; Melo-Ferreira, J.; Alves, P.C.; Mills, L.S. Function and underlying mechanisms of seasonal colour moulting in mammals and birds: What keeps them changing in a warming world? Biol. Rev. 2018, 93, 1478-1498. [CrossRef]

47. Kimura, H. Signaling molecules: Hydrogen sulfide and polysulfide. Antioxid. Redox Signal. 2015, 22, 362-376. [CrossRef]

48. Chen, J.; Hackos, D.H. TRPA1 as a drug target-Promise and challenges. Naunyn-Schmiedeberg's Arch. Pharmacol. 2015, 388, 451-463. [CrossRef]

49. Trevisan, G.; Hoffmeister, C.; Rossato, M.F.; Oliveira, S.M.; Silva, M.A.; Silva, C.R.; Fusi, C.; Tonello, R.; Minocci, D.; Guerra, G.P.; et al. TRPA1 receptor stimulation by hydrogen peroxide is critical to trigger hyperalgesia and inflammation in a model of acute gout. Free Radic. Biol. Med. 2014, 72, 200-209. [CrossRef] [PubMed]

50. Fujita, F.; Uchida, K.; Moriyama, T.; Shima, A.; Shibasaki, K.; Inada, H.; Sokabe, T.; Tominaga, M. Intracellular alkalization causes pain sensation through activation of TRPA1 in mice. J. Clin. Investig. 2008, 118, 4049-4057. [CrossRef] [PubMed]

51. Yuan, Y.; Jiang, Y.-C.; Sun, C.-K.; Chen, Q.-M. Role of the tumor microenvironment in tumor progression and the clinical applications (Review). Oncol. Rep. 2016, 35, 2499-2515. [CrossRef]

52. Baghban, R.; Roshangar, L.; Jahanban-Esfahlan, R.; Seidi, K.; Ebrahimi-Kalan, A.; Jaymand, M.; Kolahian, S.; Javaheri, T.; Zare, P. Tumor microenvironment complexity and therapeutic implications at a glance. Cell Commun. Signal. 2020, 18, 59. [CrossRef]

53. Whiteside, T.L. The tumor microenvironment and its role in promoting tumor growth. Oncogene 2008, 27, 5904-5912. [CrossRef]

54. Aller, M.; Arias, J.L.; Nava, M.P. Posttraumatic inflammation is a complex response based on the pathological expression of the nervous, immune, and endocrine functional systems. Exp. Biol. Med. 2004, 229, 170-181. [CrossRef]

55. Lluis, J.M.; Buricchi, F.; Chiarugi, P.; Morales, A.; Fernandez-Checa, J.C. Dual role of mitochondrial reactive oxygen species in hypoxia signaling: Activation of nuclear factor-KB via c-SRC- and oxidant-dependent cell death. Cancer Res. 2007, 67, 7368-7377. [CrossRef] [PubMed]

56. Jahanban-Esfahlan, R.; Seidi, K.; Shotorbani, B.B.; Jahanban-Esfahlan, A.; Yousefi, B. Combination of nanotechnology with vascular targeting agents for effective cancer therapy. J. Cell. Physiol. 2017, 233, 2982-2992. [CrossRef]

57. Jahanban-Esfahlan, R.; Seidi, K.; Zarghami, N. Tumor vascular infarction: Prospects and challenges. Int. J. Hematol. 2017, 105, 244-256. [CrossRef] [PubMed]

58. Zhang, J.-M.; An, J. Cytokines, inflammation and pain. Int. Anesth. Clin. 2009, 69, 482-489.

59. Schmidt, B.L. The neurobiology of cancer pain. Neuroscience 2014, 20, 546-562.

60. Ronga, I.; Gallucci, F.; Riccardi, F.; Uomo, G. Anorexia-cachexia syndrome in pancreatic cancer: Recent advances and new pharmacological approach. Adv. Med. Sci. 2014, 59, 1-6. [CrossRef]

61. Meng, J.; Wang, J.; Steinhoff, M.; Dolly, J.O. TNF $\alpha$ induces co-trafficking of TRPV1/TRPA1 in VAMP1-containing vesicles to the plasmalemma via Munc18-1/syntaxin1/SNAP-25 mediated fusion. Sci. Rep. 2016, 6, 21226. [CrossRef]

62. Fang, D.; Kong, L.Y.; Cai, J.; Li, S.; Liu, X.D.; Han, J.S.; Xing, G.G. Interleukin-6-mediated functional upregulation of TRPV1 receptors in dorsal root ganglion neurons through the activation of JAK/PI3K signaling pathway: Roles in the development of bone cancer pain in a rat model. Pain 2015, 156, 1124-1144. [CrossRef]

63. Couture, R.; Harrisson, M.; Vianna, R.M.J.; Cloutier, F. Kinin receptors in pain and inflammation. Eur. J. Pharmacol. 2001, 429, 161-176. [CrossRef]

64. Fox, A.; Wotherspoon, G.; McNair, K.; Hudson, L.; Patel, S.; Gentry, C.; Winter, J. Regulation and function of spinal and peripheral neuronal B1 bradykinin receptors in inflammatory mechanical hyperalgesia. Pain 2003, 104, 683-691. [CrossRef]

65. Sevcik, M.A.; Ghilardi, J.R.; Halvorson, K.G.; Lindsay, T.H.; Kubota, K.; Mantyh, P.W. Analgesic efficacy of bradykinin B1 antagonists in a murine bone cancer pain model. J. Pain 2005, 6, 771-775. [CrossRef] [PubMed]

66. Weisberg, S.P.; McCann, D.; Desai, M.; Rosenbaum, M.; Leibel, R.L.; Ferrante, A.W. Obesity is associated with macrophage accumulation in adipose tissue. J. Clin. Investig. 2003, 112, 1796-1808. [CrossRef]

67. Schecterson, L.C.; Bothwell, M. Neurotrophin receptors: Old friends with new partners. Dev. Neurobiol. 2010, 70, 332-338. [CrossRef] [PubMed]

68. Watson, J.J.; Allen, S.J.; Dawbarn, D. Targeting nerve growth factor in pain. BioDrugs 2008, 22, 349-359. [CrossRef]

69. Jimenez-Andrade, J.M.; Bloom, A.P.; Stake, J.I.; Mantyh, W.; Taylor, R.N.; Freeman, K.T.; Ghilardi, J.R.; Kuskowski, M.A.; Mantyh, P.W. Pathological sprouting of adult nociceptors in chronic prostate cancer-induced bone pain. J. Neurosci. 2010, 30, 14649-14656. [CrossRef] [PubMed] 
70. Ye, Y.; Dang, D.; Zhang, J.; Viet, C.T.; Lam, D.K.; Dolan, J.C.; Gibbs, J.L.; Schmidt, B. Nerve growth factor links oral cancer progression, pain, and cachexia. Mol. Cancer Ther. 2011, 10, 1667-1676. [CrossRef]

71. Kolokythas, A.; Cox, D.P.; Dekker, N.; Schmidt, B.L. Nerve growth factor and tyrosine kinase a receptor in oral squamous cell carcinoma: Is there an association with perineural invasion? J. Oral Maxillofac. Surg. 2010, 68, 1290-1295. [CrossRef]

72. Kato, Y.; Ozawa, S.; Miyamoto, C.; Maehata, Y.; Suzuki, A.; Maeda, T.; Baba, Y. Acidic extracellular microenvironment and cancer. Cancer Cell Int. 2013, 13, 89. [CrossRef]

73. Sennino, B.; McDonald, D.M. Controlling escape from angiogenesis inhibitors. Nat. Rev. Cancer 2012, 12, 699-709. [CrossRef]

74. Corbet, C.; Feron, O. Cancer cell metabolism and mitochondria: Nutrient plasticity for TCA cycle fueling. Biochim. Et Biophys. Acta Rev. Cancer 2017, 1868, 7-15. [CrossRef]

75. Corbet, C.; Feron, O. Tumour acidosis: From the passenger to the driver's seat. Nat. Rev. Cancer 2017, 17, 577-593. [CrossRef] [PubMed]

76. DeLeo, J.A.; Yezierski, R.P. The role of neuroinflammation and neuroimmune activation in persistent pain. Pain 2001, 90, 1-6. [CrossRef]

77. Li, B.; Cai, S.; Zhao, Y.; He, Q.; Yu, X.; Cheng, L.; Zhang, Y.; Hu, X.; Ke, M.; Chen, S.; et al. Nerve growth factor modulates the tumor cells migration in ovarian cancer through the WNT/ $\beta$-catenin pathway. Oncotarget 2016, 7, 81026-81048. [CrossRef] [PubMed]

78. Davar, G. Endothelin-1 and Metastatic Cancer Pain. Pain Med. 2001, 2, 24-27. [CrossRef]

79. Grace, M.; Birrell, M.A.; Dubuis, E.; Maher, S.A.; Belvisi, M.G. Transient receptor potential channels mediate the tussive response to prostaglandin $\mathrm{E}_{2}$ and bradykinin. Thorax 2012, 67, 891-900. [CrossRef]

80. Mantyh, P.W. Cancer pain and its impact on diagnosis, survival and quality of life. Nat. Rev. Neurosci. 2006, 7, 797-809. [CrossRef]

81. Berridge, M.J.; Lipp, P.; Bootman, M.D. The versatility and universality of calcium signalling. Nat. Rev. Mol. Cell Biol. 2000, 1, 11-21. [CrossRef] [PubMed]

82. Nilius, B.; Szallasi, A. Transient receptor potential channels as drug targets: From the science of basic research to the art of medicine. Pharmacol. Rev. 2014, 66, 676-814. [CrossRef]

83. Oprée, A.; Kress, M. Involvement of the proinflammatory cytokines tumor necrosis factor- $\alpha$, IL-1 $\beta$, and IL-6 but Not IL-8 in the development of heat hyperalgesia: Effects on heat-evoked calcitonin gene-related peptide release from rat skin. J. Neurosci. 2000, 20, 6289-6293. [CrossRef] [PubMed]

84. Nadler, R.B.; Koch, A.E.; Calhoun, E.A.; Campbell, P.L.; Pruden, D.L.; Bennett, C.L.; Yarnold, P.R.; Schaeffer, A.J. IL-1 $\beta$ and TNF- $\alpha$ IN prostatic secretions are indicators in the evaluation of men with chronic prostatitis. J. Urol. 2000, 164, 214-218. [CrossRef]

85. Watkins, L.R.; Goehler, L.E.; Relton, J.; Brewer, M.T.; Maier, S.F. Mechanisms of tumor necrosis factor- $\alpha$ (TNF- $\alpha)$ hyperalgesia. Brain Res. 1995, 692, 244-250. [CrossRef]

86. Poon, R.T.-P.; Fan, S.-T.; Wong, J. Clinical implications of circulating angiogenic factors in cancer patients. J. Clin. Oncol. 2001, 19, 1207-1225. [CrossRef] [PubMed]

87. Clapham, D.E.; Runnels, L.W.; Strübing, C. The TRP ion channel family_Review. Nat. Rev. Neurosci. 2001, 2, 387-396. [CrossRef] [PubMed]

88. Cao, E.; Morales, J.C.; Liu, B.; Qin, F.; Julius, D. TRPV1 channels are intrinsically heat sensitive and negatively regulated by phosphoinositide lipids. Neuron 2013, 77, 667-679. [CrossRef]

89. Mrozkova, P.; Spicarova, D.; Palecek, J. Hypersensitivity induced by activation of spinal cord PAR2 receptors is partially mediated by TRPV1 receptors. PLoS ONE 2016, 11, e0163991. [CrossRef]

90. Numazaki, M.; Tominaga, T.; Takeuchi, K.; Murayama, N.; Toyooka, H.; Tominaga, M. Structural determinant of TRPV1 desensitization interacts with calmodulin. Proc. Natl. Acad. Sci. USA 2003, 100, 8002-8006. [CrossRef] [PubMed]

91. Wang, S.; Joseph, J.; Ro, J.Y.; Chung, M.K. Modality-specific mechanisms of protein kinase C-induced hypersensitivity of TRPV1: S800 is a polymodal sensitization site. Pain 2015, 156, 931-941. [CrossRef]

92. Montell, C. The TRP superfamily of cation channels. Sci. STKE 2005, 2005, re3. [CrossRef]

93. Diogenes, A.; Akopian, A.; Hargreaves, K. NGF up-regulates TRPA1: Implications for orofacial pain. J. Dent. Res. 2007, 86, 550-555. [CrossRef]

94. Dai, Y.; Wang, S.; Tominaga, M.; Yamamoto, S.; Fukuoka, T.; Higashi, T.; Noguchi, K. Sensitization of TRPA1 by PAR2 contributes to the sensation of inflammatory pain. J. Clin. Investig. 2007, 117, 1979-1987. [CrossRef]

95. Lukacs, V.; Rives, J.M.; Sun, X.; Zakharian, E.; Rohacs, T. Promiscuous activation of transient receptor potential vanilloid 1 (TRPV1) channels by negatively charged intracellular lipids: The key role of endogenous phosphoinositides in maintaining channel activity. J. Biol. Chem. 2013, 288, 35003-35013. [CrossRef]

96. Lishko, P.V.; Procko, E.; Jin, X.; Phelps, C.B.; Gaudet, R. The ankyrin repeats of TRPV1 bind multiple ligands and modulate channel sensitivity. Neuron 2007, 54, 905-918. [CrossRef]

97. Lau, S.-Y.; Procko, E.; Gaudet, R. Distinct properties of $\mathrm{Ca}^{2+}$-calmodulin binding to N- and C-terminal regulatory regions of the TRPV1 channel. J. Gen. Physiol. 2012, 140, 541-555. [CrossRef]

98. Malin, S.; Molliver, D.; Christianson, J.A.; Schwartz, E.S.; Cornuet, P.; Albers, K.M.; Davis, B.M. TRPV1 and TRPA1 Function and Modulation Are Target Tissue Dependent. J. Neurosci. 2011, 31, 10516-10528. [CrossRef] [PubMed]

99. Tominaga, M.; Wada, M.; Masu, M. Potentiation of capsaicin receptor activity by metabotropic ATP receptors as a possible mechanism for ATP-evoked pain and hyperalgesia. Proc. Natl. Acad. Sci. USA 2001, 98, 6951-6956. [CrossRef] 
100. Numazaki, M.; Tominaga, T.; Toyooka, H.; Tominaga, M. Direct phosphorylation of capsaicin receptor VR1 by protein kinase C $\varepsilon$ and identification of two target serine residues. J. Biol. Chem. 2002, 277, 13375-13378. [CrossRef]

101. Sugiura, T.; Kobayashi, Y.; Oka, S.; Waku, K. Biosynthesis and degradation of anandamide and 2-arachidonoylglycerol and their possible physiological significance. Prostaglandins Leukot. Essent. Fat. Acids 2002, 66, 173-192. [CrossRef] [PubMed]

102. Stein, A.T.; Ufret-Vincenty, C.A.; Hua, L.; Santana, L.; Gordon, S.E. Phosphoinositide 3-kinase binds to TRPV1 and mediates NGF-stimulated TRPV1 trafficking to the plasma membrane. J. Gen. Physiol. 2006, 128, 509-522. [CrossRef]

103. Por, E.D.; Samelson, B.K.; Belugin, S.; Akopian, A.N.; Scott, J.D.; Jeske, N.A. PP2B/calcineurin-mediated desensitization of TRPV1 does not require AKAP150. Biochem. J. 2010, 432, 549-556. [CrossRef] [PubMed]

104. Southall, M.; Vasko, M. Prostaglandin receptor subtypes, EP3C and EP4, mediate the prostaglandin E2-induced cAMP production and sensitization of sensory neurons. J. Biol. Chem. 2001, 276, 16083-16091. [CrossRef]

105. Malmberg, A.B.; Brandon, E.P.; Idzerda, R.L.; Liu, H.; McKnight, G.S.; Basbaum, A.I. Diminished inflammation and nociceptive pain with preservation of neuropathic pain in mice with a targeted mutation of the type I regulatory subunit of cAMP-dependent protein kinase. J. Neurosci. 1997, 17, 7462-7470. [CrossRef]

106. Mohapatra, D.P.; Nau, C. Regulation of $\mathrm{Ca}^{2+}$-dependent desensitization in the vanilloid receptor TRPV1 by calcineurin and cAMP-dependent protein kinase. J. Biol. Chem. 2005, 280, 13424-13432. [CrossRef]

107. Taylor-Clark, T.E.; Undem, B.J.; MacGlashan, D.W.; Ghatta, S.; Carr, M.J.; McAlexander, M.A. Prostaglandin-induced activation of nociceptive neurons via direct interaction with transient receptor potential A1 (TRPA1). Mol. Pharmacol. 2007, 73, 274-281. [CrossRef]

108. Wang, Y.Y.; Chang, R.B.; Waters, H.N.; McKemy, D.D.; Liman, E.R. The nociceptor ion channel TRPA1 is potentiated and inactivated by permeating calcium ions. J. Biol. Chem. 2008, 283, 32691-32703. [CrossRef]

109. Ferguson, G.D.; Storm, D.R. Why calcium-stimulated adenylyl cyclases? Physiology 2004, 19, 271-276. [CrossRef]

110. Jeske, N.A.; Diogenes, A.; Ruparel, N.B.; Fehrenbacher, J.C.; Henry, M.; Akopian, A.N.; Hargreaves, K.M. A-kinase anchoring protein mediates TRPV1 thermal hyperalgesia through PKA phosphorylation of TRPV1. Pain 2008, 138, 604-616. [CrossRef] [PubMed]

111. Fischer, M.J.; Btesh, J.; McNaughton, P. Disrupting sensitization of transient receptor potential vanilloid subtype 1 inhibits inflammatory hyperalgesia. J. Neurosci. 2013, 33, 7407-7414. [CrossRef] [PubMed]

112. Zimova, L.; Barvikova, K.; Macikova, L.; Vyklicka, L.; Sinica, V.; Barvik, I.; Vlachova, V. Proximal C-terminus serves as a signaling hub for TRPA1 channel regulation via its interacting molecules and supramolecular complexes. Front. Physiol. 2020, 11, 189. [CrossRef] [PubMed]

113. Lukacs, V.; Thyagarajan, B.; Varnai, P.; Balla, A.; Balla, T.; Rohacs, T. Dual regulation of TRPV1 by phosphoinositides. J. Neurosci. 2007, 27, 7070-7080. [CrossRef]

114. Samad, A.; Sura, L.; Benedikt, J.; Ettrich, R.; Minofar, B.; Teisinger, J.; Vlachova, V. The C-terminal basic residues contribute to the chemical- and voltage-dependent activation of TRPA1. Biochem. J. 2010, 433, 197-204. [CrossRef]

115. Kádková, A.; Synytsya, V.; Krusek, J.; Zímová, L.; Vlachová, V. Molecular basis of TRPA1 regulation in nociceptive neurons. A review. Physiol. Res. 2017, 66, 425-439. [CrossRef] [PubMed]

116. Redmond, W.J.; Gu, L.; Camo, M.; McIntyre, P.; Connor, M. Ligand determinants of fatty acid activation of the pronociceptive ion channel TRPA1. PeerJ 2014, 2, e248. [CrossRef] [PubMed]

117. Gouin, O.; L’Herondelle, K.; Lebonvallet, N.; Le Gall-Ianotto, C.; Sakka, M.; Buhé, V.; Plée-Gautier, E.; Carré, J.-L.; Lefeuvre, L.; Misery, L.; et al. TRPV1 and TRPA1 in cutaneous neurogenic and chronic inflammation: Pro-inflammatory response induced by their activation and their sensitization. Protein Cell 2017, 8, 644-661. [CrossRef]

118. Rohacs, T. Regulation of transient receptor potential channels by the phospholipase C pathway. Adv. Biol. Regul. 2013, 53, 341-355. [CrossRef]

119. Jeske, N.A.; Patwardhan, A.M.; Ruparel, N.B.; Akopian, A.N.; Shapiro, M.S.; Henry, M.A. A-kinase anchoring protein 150 controls protein kinase C-mediated phosphorylation and sensitization of TRPV1. Pain 2009, 146, 301-307. [CrossRef] [PubMed]

120. Zhang, X.; Li, L.; McNaughton, P.A. Proinflammatory mediators modulate the heat-activated ion channel TRPV1 via the scaffolding protein AKAP79/150. Neuron 2008, 59, 450-461. [CrossRef]

121. Docherty, R.J.; Yeats, J.C.; Bevan, S.; Boddeke, H.W.G.M. Inhibition of calcineurin inhibits the desensitization of capsaicin-evoked currents in cultured dorsal root ganglion neurones from adult rats. Pflugers Arch. Eur. J. Physiol. 1996, 431, 828-837. [CrossRef]

122. Patwardhan, A.M.; Jeske, N.A.; Price, T.; Gamper, N.; Akopian, A.N.; Hargreaves, K.M. The cannabinoid WIN 55,212-2 inhibits transient receptor potential vanilloid 1 (TRPV1) and evokes peripheral antihyperalgesia via calcineurin. Proc. Natl. Acad. Sci. USA 2006, 103, 11393-11398. [CrossRef]

123. Galoyan, S.M.; Petruska, J.C.; Mendell, L.M. Mechanisms of sensitization of the response of single dorsal root ganglion cells from adult rat to noxious heat. Eur. J. Neurosci. 2003, 18, 535-541. [CrossRef]

124. Zhu, W.; Oxford, G.S. Phosphoinositide-3-kinase and mitogen activated protein kinase signaling pathways mediate acute NGF sensitization of TRPV1. Mol. Cell. Neurosci. 2007, 34, 689-700. [CrossRef]

125. Zhuang, Z.-Y.; Xu, H.; Clapham, D.E.; Ji, R.-R. Phosphatidylinositol 3-kinase activates ERK in primary sensory neurons and mediates inflammatory heat hyperalgesia through TRPV1 sensitization. J. Neurosci. 2004, 24, 8300-8309. [CrossRef] [PubMed]

126. Bandell, M.; Story, G.M.; Hwang, S.W.; Viswanath, V.; Eid, S.R.; Petrus, M.J.; Earley, T.J.; Patapoutian, A. Noxious cold ion channel TRPA1 is activated by pungent compounds and bradykinin. Neuron 2004, 41, 849-857. [CrossRef] 
127. Chuang, H.-H.; Prescott, E.D.; Kong, H.; Shields, S.; Jordt, S.-E.; Basbaum, A.I.; Chao, M.; Julius, D. Bradykinin and nerve growth factor release the capsaicin receptor from PtdIns(4,5)P2-mediated inhibition. Nature 2001, 411, 957-962. [CrossRef]

128. Obata, K.; Katsura, H.; Mizushima, T.; Yamanaka, H.; Kobayashi, K.; Dai, Y.; Noguchi, K. TRPA1 induced in sensory neurons contributes to cold hyperalgesia after inflammation and nerve injury (Journal of Clinical Investigation (2005) 115, (2393-2401)). J. Clin. Investig. 2010, 120, 394. [CrossRef]

129. Andrade, E.; Meotti, F.; Calixto, J. TRPA1 antagonists as potential analgesic drugs. Pharmacol. Ther. 2011, 133, 189-204. [CrossRef] [PubMed]

130. Doerner, J.F.; Gisselmann, G.; Hatt, H.; Wetzel, C.H. Transient receptor potential channel A1 is directly gated by calcium ions. J. Biol. Chem. 2007, 282, 13180-13189. [CrossRef] [PubMed]

131. Morgan, K.; Sadofsky, L.R.; Crow, C.; Morice, A.H. Human TRPM8 and TRPA1 pain channels, including a gene variant with increased sensitivity to agonists (TRPA1 R797T), exhibit differential regulation by SRC-tyrosine kinase inhibitor. Biosci. Rep. 2014, 34, 469-478. [CrossRef] [PubMed]

132. Zhang, X.; Huang, J.; McNaughton, P. NGF rapidly increases membrane expression of TRPV1 heat-gated ion channels. EMBO J. 2005, 24, 4211-4223. [CrossRef]

133. Talavera, K.; Startek, J.B.; Alvarez-Collazo, J.; Boonen, B.; Alpizar, Y.A.; Sanchez, A.; Naert, R.; Nilius, B. Mammalian transient receptor potential TRPA1 channels: From structure to disease. Physiol. Rev. 2020, 100, 725-803. [CrossRef]

134. Lennertz, R.C.; Kossyreva, E.A.; Smith, A.K.; Stucky, C.L. TRPA1 Mediates Mechanical Sensitization in Nociceptors during Inflammation. PLoS ONE 2012, 7, e43597. [CrossRef]

135. Bonnington, J.K.; McNaughton, P.A. Signalling pathways involved in the sensitisation of mouse nociceptive neurones by nerve growth factor. J. Physiol. 2003, 551, 433-446. [CrossRef]

136. Zhu, W.; Galoyan, S.M.; Petruska, J.; Oxford, G.S.; Mendell, L. A developmental switch in acute sensitization of small Dorsal Root Ganglion (DRG) neurons to capsaicin or noxious heating by NGF. J. Neurophysiol. 2004, 92, 3148-3152. [CrossRef]

137. Neri, D.; Supuran, C.T. Interfering with $\mathrm{pH}$ regulation in tumours as a therapeutic strategy. Nat. Rev. Drug Discov. 2011, 10, 767-777. [CrossRef] [PubMed]

138. Koplas, P.A.; Rosenberg, R.L.; Oxford, G.S. The role of calcium in the desensitization of capsaicin responses in rat dorsal root ganglion neurons. J. Neurosci. 1997, 17, 3525-3537. [CrossRef]

139. Martin, T.; Ye, L.; Sanders, A.; Lane, J.; Jiang, W. Cancer invasion and metastasis: Molecular and cellular perspective cancer invasion and metastasis: The role of cell adhesion molecules. Cancer Invasion Metastasis Mol. Cell Perspect 2014, 9, 135-168.

140. Mantyh, P. Bone cancer pain: Causes, consequences, and therapeutic opportunities. Pain 2013, 154, S54-S62. [CrossRef] [PubMed]

141. Teitelbaum, S.L. Bone resorption by osteoclasts. Science 2000, 289, 1504-1508. [CrossRef] [PubMed]

142. Jordt, S.-E.; Tominaga, M.; Julius, D. Acid potentiation of the capsaicin receptor determined by a key extracellular site. Proc. Natl. Acad. Sci. USA 2000, 97, 8134-8139. [CrossRef] [PubMed]

143. Hellwig, N.; Plant, T.D.; Janson, W.; Schäfer, M.; Schultz, G. TRPV1 Acts as proton channel to induce acidification in nociceptive neurons. J. Biol. Chem. 2004, 279, 34553-34561. [CrossRef]

144. Wang, G.J.; Randall, R.D.; Thayer, S.A. Glutamate-induced intracellular acidification of cultured hippocampal neurons demonstrates altered energy metabolism resulting from $\mathrm{Ca}^{2+}$ loads. J. Neurophysiol. 1994, 72, 2563-2569. [CrossRef] [PubMed]

145. Paalasmaa, P.; Kaila, K. Role of voltage-gated calcium channels in the generation of activity-induced extracellular $\mathrm{pH}$ transients in the rat hippocampal slice. J. Neurophysiol. 1996, 75, 2354-2360. [CrossRef]

146. Wang, Y.Y.; Chang, R.B.; Liman, E.R. TRPA1 is a component of the nociceptive response to $\mathrm{CO}_{2}$. J. Neurosci. 2010, 30, 12958-12963. [CrossRef]

147. Dai, Y. TRPs and pain. Semin Immunopathol. 2016, 38, 277-291. [CrossRef]

148. Moparthi, L.; Zygmunt, P.M. Human TRPA1 is an inherently mechanosensitive bilayer-gated ion channel. Cell Calcium 2020, 91, 102255. [CrossRef] [PubMed]

149. Hayes, J.D.; Dinkova-Kostova, A.T.; Tew, K.D. Oxidative stress in cancer. Cancer Cell 2020, 38, 167-197. [CrossRef] [PubMed]

150. Lehto, S.G.; Tamir, R.; Deng, H.; Klionsky, L.; Kuang, R.; Le, A.; Lee, D.; Louis, J.-C.; Magal, E.; Manning, B.H.; et al. Antihyperalgesic effects of (R,E)-N-(2-Hydroxy-2,3-dihydro-1H-inden-4-yl)-3-(2-(piperidin-1-yl)-4-(trifluoromethyl)phenyl)-acrylamide (AMG8562), a novel transient receptor potential vanilloid type 1 modulator that does not cause hyperthermia in rats. J. Pharmacol. Exp. Ther. 2008, 326, 218-229. [CrossRef]

151. Hashim, A.I.; Zhang, X.; Wojtkowiakk, J.W.; Martinez, G.V.; Gillies, R.J. Imaging pH and metastasis. NMR Biomed. 2011, 24, 582-591. [CrossRef] [PubMed]

152. Stubbs, M.; McSheehy, P.M.; Griffiths, J.R.; Bashford, C. Causes and consequences of tumour acidity and implications for treatment. Mol. Med. Today 2000, 6, 15-19. [CrossRef]

153. Bode, A.M.; Dong, Z. The Two Faces of Capsaicin: Figure 1. Cancer Res. 2011, 71, 2809-2814. [CrossRef]

154. Hayman, M.; Kam, P.C. Capsaicin: A review of its pharmacology and clinical applications. Curr. Anaesth. Crit. Care 2008, 19, 338-343. [CrossRef]

155. Szallasi, A.; Cortright, D.N.; Blum, C.A.; Eid, S.R. The vanilloid receptor TRPV1: 10 years from channel cloning to antagonist proof-of-concept. Nat. Rev. Drug Discov. 2007, 6, 357-372. [CrossRef]

156. Remadevi, R.; Szallisi, A. Adlea (ALGRX-4975), an injectable capsaicin (TRPV1 receptor agonist) formulation for longlasting pain relief. IDrugs Investig. Drugs J. 2008, 11, 120-132. 
157. Nolano, M.; Simone, D.A.; Wendelschafer-Crabb, G.; Johnson, T.; Hazen, E.; Kennedy, W.R. Topical capsaicin in humans: Parallel loss of epidermal nerve fibers and pain sensation. Pain 1999, 81, 135-145. [CrossRef]

158. Fattori, V.; Hohmann, M.S.N.; Rossaneis, A.C.; Pinho-Ribeiro, F.A.; Verri, W.A. Capsaicin: Current Understanding of Its Mechanisms and Therapy of Pain and Other Pre-Clinical and Clinical Uses. Molecules 2016, 21, 844. [CrossRef]

159. Smith, H.; Brooks, J.R. Capsaicin-Based Therapies for Pain Control. Prog. Drug Res. 2014, 68, 129-146. [CrossRef]

160. Watson, P.N.; Evans, R.J.; Watt, V.R.; Birkett, N. Post-herpetic neuralgia: 208 cases. Pain 1988, 35, 289-297. [CrossRef]

161. Kiani, J.; Sajedi, F.; Nasrollahi, S.A.; Esna-Ashari, F. A randomized clinical trial of efficacy and safety of the topical clonidine and capsaicin in the treatment of painful diabetic neuropathy. J. Res. Med. Sci. 2015, 20, 359-363. [PubMed]

162. Zis, P.; Apsokardos, A.; Isaia, C.; Sykioti, P.; Vadalouca, A. Posttraumatic and postsurgical neuropathic pain responsive to treatment with capsaicin 8\% topical patch. Pain Physician 2014, 17, E213-E218.

163. Robbins, W.R.; Staats, P.S.; Levine, J.; Fields, H.L.; Allen, R.W.; Campbell, J.N.; Pappagallo, M. Treatment of intractable pain with topical large-dose capsaicin: Preliminary report. Anesth. Analg. 1998, 86, 579-583. [CrossRef]

164. Basith, S.; Cui, M.; Hong, S.; Choi, S. Harnessing the Therapeutic Potential of Capsaicin and Its Analogues in Pain and Other Diseases. Molecules 2016, 21, 966. [CrossRef] [PubMed]

165. Derry, S.; Rice, A.S.; Cole, P.; Tan, T.; Moore, R.A. Topical capsaicin (high concentration) for chronic neuropathic pain in adults. Cochrane Database Syst. Rev. 2017, 2021, CD007393. [CrossRef]

166. Ellison, N.; Loprinzi, C.L.; Kugler, J.; Hatfield, A.K.; Miser, A.; Sloan, J.A.; Wender, D.B.; Rowland, K.M.; Molina, R.; Cascino, T.L.; et al. Phase III placebo-controlled trial of capsaicin cream in the management of surgical neuropathic pain in cancer patients. J. Clin. Oncol. 1997, 15, 2974-2980. [CrossRef]

167. Berger, A.; Henderson, M.; Nadoolman, W.; Duffy, V.; Cooper, D.; Saberski, L.; Bartoshuck, L. Oral capsaicin provides temporary relief for oral mucositis pain secondary to chemotherapy/radiation therapy. J. Pain Symptom. Manag. 1995, 10, 243-248. [CrossRef]

168. Bölcskei, K.; Tékus, V.; Dézsi, L.; Szolcsányi, J.; Petho, G. Antinociceptive desensitizing actions of TRPV1 receptor agonists capsaicin, resiniferatoxin and $\mathrm{N}$-oleoyldopamine as measured by determination of the noxious heat and cold thresholds in the rat. Eur. J. Pain 2010, 14, 480-486. [CrossRef] [PubMed]

169. Ghilardi, J.R.; Röhrich, H.; Lindsay, T.H.; Sevcik, M.A.; Schwei, M.J.; Kubota, K.; Halvorsonj, J.; Poblete, J.; Chaplan, S.; Dublin, A.; et al. Selective blockade of the capsaicin receptor TRPV1 attenuates bone cancer pain. J. Neurosci. 2005, 25, 3126-3131. [CrossRef]

170. Namazi, H. The effect of epidural resiniferatoxin in the neuropathic pain rat model randomized trial: A complementary mechanism. Pain Physician. 2012, 15, E750. [CrossRef]

171. Heiss, J.; Iadarola, M.; Cantor, F.; Oughourli, A.; Smith, R.; Mannes, A. (364) A Phase I study of the intrathecal administration of resiniferatoxin for treating severe refractory pain associated with advanced cancer. J. Pain 2014, 15, S67. [CrossRef]

172. Mannes, A.; Hughes, M.; Quezado, Z.; Berger, A.; Fojo, T.; Smith, R.; Butman, J.; Lonser, R.; Ladarola, M. Resiniferatoxin, a potent TRPV1 agonist: Intrathecal administration to treat severe pain associated with advanced cancer-case report. J. Pain 2010, 11, S43. [CrossRef]

173. Watson, C.P.; Tyler, K.; Bickers, D.R.; Millikan, L.E.; Smith, S.; Coleman, E. A randomized vehicle-controlled trial of topical capsaicin in the treatment of postherpetic neuralgia. Clin. Ther. 1993, 15, 510-526. [CrossRef]

174. Gomes Júnior, A.L.; Islam, M.T.; Nicolau, L.A.D.; De Souza, L.K.M.; de Souza Lopes Araújo, T.; Lopes De Oliveira, G.A.; Nogueira, K.; Lopes da Silva, L.; Medieros, J.; Mubarak, M.; et al. Anti-Inflammatory, Antinociceptive, and Antioxidant Properties of Anacardic Acid in Experimental Models. ACS Omega 2020, 5, 19506-19515. [CrossRef] [PubMed]

175. Bartolome, A.P.; Villaseñor, I.M.; Yang, W.C. Bidens pilosa L. (Asteraceae): Botanical properties, traditional uses, phytochemistry, and pharmacology. Evid.-Based Complementary Altern. Med. 2013, 2013, 340215. [CrossRef]

176. Xuan, T.D.; Khanh, T.D. Chemistry and pharmacology of Bidens pilosa: An overview. J. Pharm. Investig. 2016, 46, 91-132. [CrossRef] [PubMed]

177. Guerrini, A.; Sacchetti, G.; Rossi, D.; Paganetto, G.; Muzzoli, M.; Andreotti, E.; Tognolini, M.; Maldonado, M.E.; Bruni, R. Bioactivities of Piper aduncum L. and Piper obliquum Ruiz \& Pavon (Piperaceae) essential oils from Eastern Ecuador. Environ. Toxicol. Pharmacol. 2009, 27, 39-48. [CrossRef]

178. Santos, M.L.; Magalhães, C.F.; da Rosa, M.B.; de Assis Santos, D.; Brasileiro, B.G.; de Carvalho, L.M.; Barreto da Silva, M.; Zani, C.; Pessoa de Siqueira, E.; Peres, R.; et al. Antifungal activity of extracts from Piper aduncum leaves prepared by different solvents and extraction techniques against dermatophytes Trichophyton rubrum and Trichophyton interdigitale. Braz. J. Microbiol. 2013, 44, 1275-1278. [CrossRef]

179. López, M.A.; Stashenko, E.; Fuentes, J.L. Chemical composition and antigenotoxic properties of Lippia alba essential oils. Genet. Mol. Biol. 2011, 34, 479-488. [CrossRef] [PubMed]

180. Ezeonwumelu, J.O.C.; Ntale, M.; Ogbonnia, S.O.; Agwu, E.; Tanayen, J.K.; Adedeji, A.A.; Okonkwo, C.O.; Akunne, A.A.; Ebosie, J.C.; Byarugaba, F. Analgesic Appraisal of Bidens pilosa (Asteraceae) Leaf Extracts Used in Management of Oral Lesion Pain in HIV/AIDS Patients in Rodents. Pharmacol. Pharm. 2018, 9, 175-192. [CrossRef]

181. Haldar, S.; Kar, B.; Dolai, N.; Kumar, R.B.S.; Behera, B.; Haldar, P.K. In Vivo anti-nociceptive and anti-inflammatory activities of Lippia alba. Asian Pacific J. Trop Dis. 2012, 2, S667-S670. [CrossRef]

182. McNamara, F.N.; Randall, A.; Gunthorpe, M.J. Effects of piperine, the pungent component of black pepper, at the human vanilloid receptor (TRPV1). Br. J. Pharmacol. 2005, 144, 781-790. [CrossRef] 
183. Pearce, L.V.; Petukhov, P.A.; Szabo, T.; Kedei, N.; Bizik, F.; Kozikowski, A.P.; Blumberg, P. Evodiamine functions as an agonist for the vanilloid receptor TRPV1. Org. Biomol. Chem. 2004, 2, 2281-2286. [CrossRef]

184. Bisogno, T.; Hanuš, L.; De Petrocellis, L.; Tchilibon, S.; Ponde, D.E.; Brandi, I.; Moriello, A.S.; Davis, J.B.; Mechoulam, R.; Di Marzo, V. Molecular targets for cannabidiol and its synthetic analogues: Effect on vanilloid VR1 receptors and on the cellular uptake and enzymatic hydrolysis of anandamide. Br. J. Pharmacol. 2001, 134, 845-852. [CrossRef] [PubMed]

185. Andre, E.; Campi, B.; Trevisani, M.; Ferreira, J.; Malheiros, A.; Yunes, R.A.; Calixto, J.B.; Geppetti, P. Pharmacological characterisation of the plant sesquiterpenes polygodial and drimanial as vanilloid receptor agonists. Biochem. Pharmacol. 2006, 71, 1248-1254. [CrossRef]

186. Szallasi, A.; Jonassohn, M.; Ács, G.; Bíró, T.; Ács, P.; Blumberg, P.; Sterner, O. The stimulation of capsaicin-sensitive neurones in a vanilloid receptor-mediated fashion by pungent terpenoids possessing an unsaturated 1,4-dialdehyde moiety. Br. J. Pharmacol. 1996, 119, 283-290. [CrossRef]

187. Tóth, A.; Kedei, N.; Szabó, T.; Wang, Y.; Blumberg, P.M. Thapsigargin binds to and inhibits the cloned vanilloid receptor-1. Biochem. Biophys. Res. Commun. 2002, 293, 777-782. [CrossRef]

188. Dessaint, J.; Yu, W.; Krause, J.E.; Yue, L. Yohimbine inhibits firing activities of rat dorsal root ganglion neurons by blocking $\mathrm{Na}^{+}$ channels and vanilloid VR1 receptors. Eur. J. Pharmacol. 2003, 485, 11-20. [CrossRef] [PubMed]

189. Jordt, S.E.; Bautista, D.M.; Chuang, H.H.; McKemy, D.D.; Zygmunt, P.M.; Högestätt, E.D.; Högestätt, E.; Meng, I.; Julius, D. Mustard oils and cannabinoids excite sensory nerve fibres through the TRP channel ANKTM1. Nature 2004, 427, $260-265$. [CrossRef]

190. Xu, H.; Delling, M.; Jun, J.C.; Clapham, D.E. Oregano, thyme and clove-derived flavors and skin sensitizers activate specific TRP channels. Nat. Neurosci. 2006, 9, 628-635. [CrossRef]

191. Macpherson, L.J.; Hwang, S.W.; Miyamoto, T.; Dubin, A.E.; Patapoutian, A.; Story, G.M. More than cool: Promiscuous relationships of menthol and other sensory compounds. Mol. Cell. Neurosci. 2006, 32, 335-343. [CrossRef]

192. Yang, B.H.; Piao, Z.G.; Kim, Y.-B.; Lee, C.-H.; Lee, J.K.; Park, K.; Kim, J.S.; Oh, S.B. Activation of Vanilloid Receptor 1 (VR1) by Eugenol. J. Dent. Res. 2003, 82, 781-785. [CrossRef]

193. Iwasaki, Y.; Morita, A.; Iwasawa, T.; Kobata, K.; Sekiwa, Y.; Morimitsu, Y.; Kubota, K.; Watanabe, T. A nonpungent component of steamed ginger-[10]-shogaol-increases adrenaline secretion via the activation of TRPV1. Nutr. Neurosci. 2006, 9, 169-178. [PubMed]

194. Xu, H.; Blair, N.T.; Clapham, D.E. Camphor Activates and Strongly Desensitizes the Transient Receptor Potential Vanilloid Subtype 1 Channel in a Vanilloid-Independent Mechanism. J. Neurosci. 2005, 25, 8924-8937. [CrossRef] [PubMed]

195. Macpherson, L.; Geierstanger, B.H.; Viswanath, V.; Bandell, M.; Eid, S.R.; Hwang, S.W.; Patapoutian, A. The Pungency of Garlic: Activation of TRPA1 and TRPV1 in Response to Allicin. Curr. Biol. 2005, 15, 929-934. [CrossRef] [PubMed]

196. Dolai, N.; Karmakar, I.; Kumar, R.B.S.; Haldar, P.K. CNS depressant activity of Castanopsis indica leaves. Orient. Pharm. Exp. Med. 2012, 12, 135-140. [CrossRef] 